\title{
La década de los sesenta en El Salvador: un modelo de negación dialéctica
}

\author{
RICARDO RIBERA \\ Departamento de Filosofía, \\ Universidad Centroamericana "José Simeón Cañas" \\ Antiguo Cuscatlán, El Salvador
}

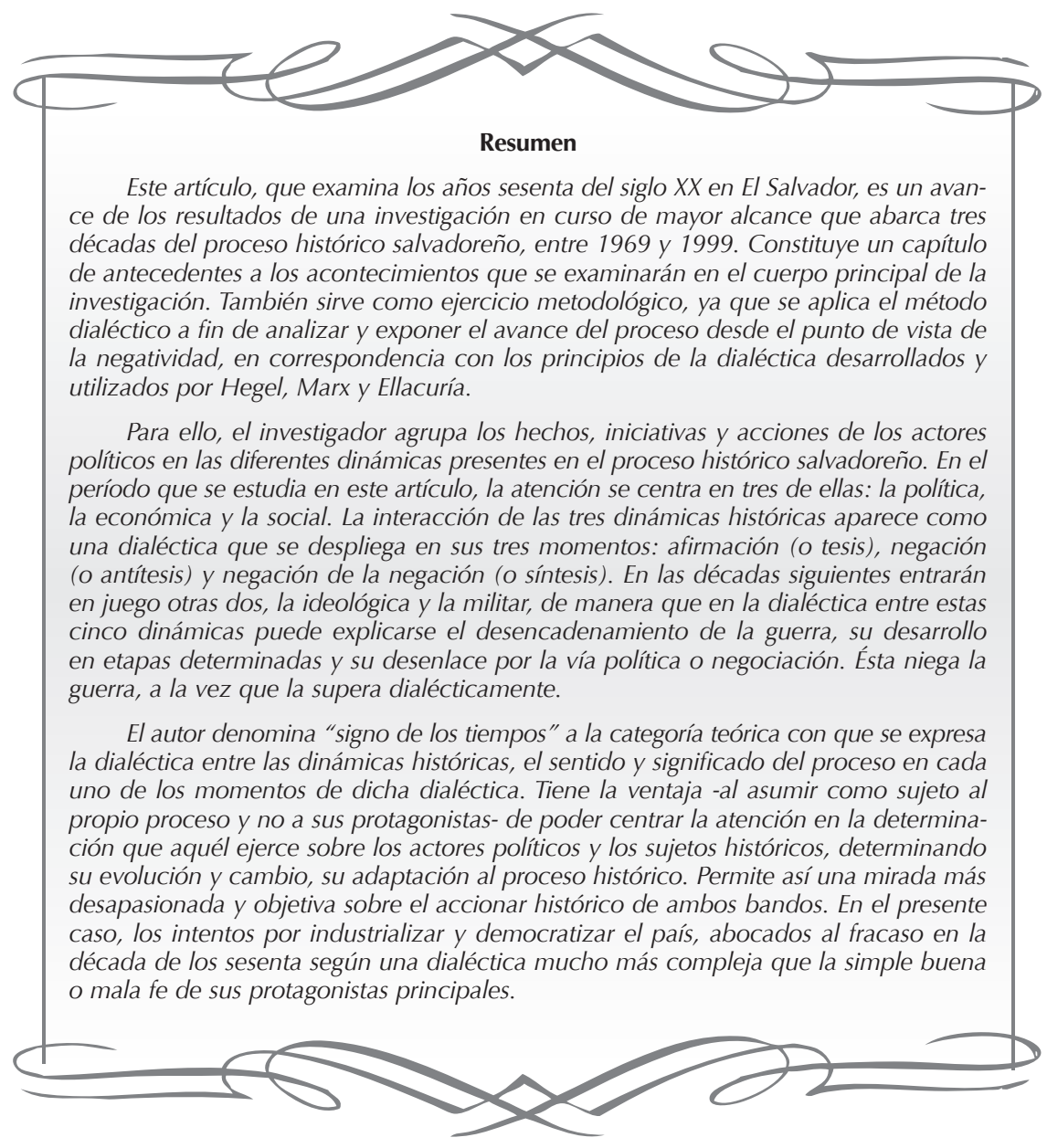


Palabras clave:

El Salvador, historia contemporánea, dinámicas históricas, dialéctica, evolución, desarrollo, modelo económico, régimen político, conflicto social, democratización, oposición, crisis, represión, dictadura, guerra.

\section{La magia del número nueve}

V

amos aquí a hablar de la década de los sesenta, es decir, de los años previos a 1969, que es la fecha de arranque de nuestro estudio. ¿Por qué tomar la década entera? ¿Por qué no una cantidad menor o mayor de años? Desde luego, resulta más sencillo asumir un período de diez años, pero ésta no puede ser razón suficiente.

Sin embargo, contamos a nuestro favor con un elemento casual que nos va a permitir la comodidad de operar con una periodización "fácil" de aceptar y de recordar para el gran público: mostrar por separado las décadas del proceso salvadoreño, hablar de los años setenta, de los ochenta y de los noventa. Al establecer una periodización histórica, lo más lógico y natural es tomar ciertos acontecimientos relevantes, de considerable peso, magnitud o trascendencia, como indicativos del fin de una fase y de inicio a la siguiente. Ciertos hechos históricos son así como "mojones" en el camino que se va a recorrer.

La casualidad, puesto que ningún elemento de necesidad está presente en ello, es la que rige en este caso. Es total consecuencia del azar, del caprichoso destino, que el proceso salvadoreño presente acontecimientos de esa naturaleza que hemos señalado, justamente en años terminados en nueve. Tenemos en 1969 la guerra entre El Salvador y Honduras, hecho de gran relevancia y graves consecuencias, que hemos adoptado como punto de partida del fragmento de proceso histórico que vamos a investigar. Pero es que, además, tenemos en 1979 el golpe de Estado del 15 de octubre, que puso fin al régimen político de dictadura militar y abrió la crisis política, en el marco de la cual se desencadenó la guerra civil. 1989 , con la gran ofensiva insurgente en el mes de noviembre, es otro punto de inflexión en el proceso, pues genera el momento de despegue de la negociación. Por último, también 1999 nos parece una fecha significativa pues, a nuestro modo de ver, es el año en que culmina la transición, como ya tendremos oportunidad de argumentar en su debido momento.

La última de las casualidades numéricas -o cronológicas, como se prefiera- lo hallamos en el año 1959: fecha del triunfo de la revo- 
lución cubana. No forma parte de la "historia salvadoreña" y uno tendería a pensar por tanto que "no tiene nada que ver". No obstante, resulta un acontecimiento muy significativo para nuestro proceso histórico, al menos en la perspectiva analítica en que vamos aquí a enfocarlo. Ya vamos a tener la ocasión de discutirlo en las próximas páginas. De momento nos adelantamos en anunciarlo para así dejar establecida esta quinta casualidad cronológica que nos permite, al período de las tres décadas en que nos centramos -según indica el subtítulo de esta obra- añadir una década más, la anterior, como antecedente inmediato al mismo.

La consecuencia es que podemos contar con la comodidad de referirnos a "la década de los sesenta", o simplemente a "los años sesenta", al momento de hablar de este período previo. Fuera más engorroso si la etapa de antecedentes por su objetividad fáctica fuera, por ejemplo, de 1963 a 1969. Igualmente ocurre en las tres fases siguientes, entre 1969 y 1999. Los hechos tuvieron con nosotros esta gentileza inesperada de facilitar para el lenguaje y para el entendimiento, en nítidas décadas históricas, sus etapas objetivas. Más para el lenguaje que para el entendimiento: en realidad cada década debería empezar y terminar un año después, así como el siglo XX empezó en 1901 y no va a terminar sino hasta el fin del año 2000. A no ser que el primer siglo de nuestra era haya tenido sólo 99 años. No importa. Quedémonos con las décadas convencionales. Es más cómodo.

\section{¿Por dónde empezar?}

Debemos empezar por lo que ya sabemos. Con respecto a la década de los sesenta, lo que de entrada conocemos es lo que ya hemos dejado reseñado: cómo culminó. Pero si partimos de este acontecimiento -la guerra entre El Salvador y Honduras-, difícilmente vamos a poder avanzar más. No es suficiente para indicarnos el "factor resultante" pues se trata de un hecho aislado. No sabemos aún cuál sea su naturaleza, cómo debemos considerarlo, si como un hecho militar o político, si económico o social. Una dinámica histórica es un conjunto de iniciativas y acontecimientos; no podemos precisarla desde un único hecho histórico. En conclusión, desde esa dinámica resultante que todavía no conocemos nos resulta imposible conocer las dinámicas dominante y determinante.

En lugar de comenzar por el final, tratemos ahora de empezar por el principio. El comienzo de la relación dialéctica se establece desde el factor determinante. Pero nada sabemos de su contenido, nada nos indica cuál pueda ser la dinámica determinante en la década de los 
sesenta. No obstante, hay algo que sí sabemos: ese factor determinará al factor dominante. Es el único hilo que puede conducirnos hacia él. Es decir, desde la dinámica dominante podremos saber de la dinámica determinante, en un proceso lógico que va en dirección inversa a como en verdad funciona, dialéctica y cronológicamente.

Por lo tanto, este segundo intento nos encamina hacia un tercer ensayo, el de arrancar desde la dinámica dominante. ¡La tercera ha de ser la vencida! El mismo concepto de lo que es factor dominante indica que no ha de ser difícil averiguar de él. Debe ser una dinámica que "domine" la década, que se imponga claramente sobre el resto de dinámicas, sobre el conjunto de acontecimientos, iniciativas, aspiraciones y hechos. Es decir, por su misma definición, la dinámica dominante debe ser algo que "está a la vista", que vamos a poder identificar sin la mayor vacilación, que no despierta dudas.

El procedimiento metodológico avanza por tres pasos sucesivos. Lo primero es partir de lo que ya sabemos previamente sobre el período. Algo tenemos que saber ya de él, debemos contar con un mínimo conocimiento inicial. Lo segundo es la formulación de una hipótesis teórica, de una inicial explicación tentativa. Lo tercero es hacer acopio de información adicional, reunir el máximo de datos, de material em- pírico, de hechos, a fin de verificar la hipótesis planteada. Esta puede resultar comprobada o falseada. Vamos a desecharla y sustituirla, modificaremos o afinaremos aquella hipótesis inicial, si resulta falseada en el paso tercero. O bien, resulta corroborada y queda así fijada.

Pues bien, lo que sabemos inicialmente de los años sesenta en El Salvador es que ése fue el tiempo en que se conformó el Mercado Común Centroamericano, MCCA. En esta década, el país entró a un proceso de industrialización. Se intentaba así salir del modelo económico agroexportador centrado en el café. Por un lado, aumentando el papel de las exportaciones agropecuarias tradicionales distintas del café (azúcar y algodón) y, por otro, incrementando el peso de las exportaciones no tradicionales (agropecuarias e industriales). La experiencia se inició con la década y terminó al darse el conflicto con Honduras. Los años sesenta estuvieron marcados, "dominados", por las expectativas, las esperanzas y los esfuerzos puestos en la economía, por hacer despegar al país hacia el verdadero desarrollo económico, social y humano. La dinámica dominante en la década de los sesenta fue, indiscutiblemente, la dinámica económica. ¿Cuál habrá sido entonces la dinámica determinante? Esta pregunta es más difícil de contestar y necesitaremos reunir mucha más información para abordarla. 


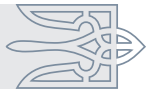

El orden de exposición a menudo no coincide con el orden seguido en la investigación, puesto que la una y la otra obedecen a lógicas diferentes. El orden lógico de exposición es entonces distinto al que siguió el investigador en su labor. El lector es conducido de forma semejante a los llamados "niños exploradores", quienes normalmente no exploran nada, se limitan a seguir al guía. Éste sabe por dónde llevarlos, conoce el camino y el lugar al que se encaminan. Lo mismo podría decir el autor: "yo ya he estado ahí". Esa es su ventaja sobre el lector.

También puede el guía ahorrarle al grupo el camino escabroso e ir al punto de destino por sendas más cómodas. Un buen incentivo es describir de antemano el paisaje que espera y las cualidades del lugar de llegada. También aquí nosotros podemos ahorrarnos la larga caminata y dejarnos transportar al punto de la conclusión. En este caso quedará enunciado en forma de tesis, de afirmación que hace el autor, desde el conocimiento que tiene del terreno sobre el que avanza. Sólo tras un estudio del material empírico, conociendo multitud de hechos, cuando se domina bien la región por la que se camina, puede entonces trazarse un mapa del terreno, un croquis que simplifique los detalles y muestre la dirección a seguir. El autor hizo de explorador cuando investigaba, pero al momento de escribir ya no lo es más, sino que se comporta como un guía.

¿Cuál es la dinámica determinante del proceso en la década de los sesenta? La respuesta nos sitúa de un solo golpe al final del camino, sobre terreno ya explorado previamente, sin sendas que desbrozar. La tesis que afirma el autor va a sorprender a más de alguno, sobre todo a quienes, desde influencias marxistas, tienden a pensar que lo determinante es siempre lo económico. $\mathrm{Y}$ por eso mismo resulta más interesante haber tomado como ejemplo la década de los sesenta, porque en este período no es la dinámica económica la que aparece como determinante. Así nos diferenciamos, desde un inicio y con claridad, de la tradicional conceptualización marxista. Aquí vamos a plantear que es la dinámica política la que ha jugado en los sesenta el papel de factor determinante. Lo cual no anula la determinación "en última instancia" que tiene la infraestructura económica, como ya habíamos concedido antes. Al decir "factor determinante" -no estará de más recordarlo de nuevo- nos estamos refiriendo a la sobredeterminación o determinación en segunda instancia, según la caracterización que hicimos al exponer la categoría signo de los tiempos. Es decir, la dinámica política sobredeterminó en esa época que haya sido la dinámica económica 
la que se destacara como dinámica dominante de la misma.

Dicho esto, debemos exponer resumidamente los hechos para justificar esa afirmación. Y también para caracterizar el contenido de dicha dinámica política. Es decir, precisar el signo de los tiempos hacia el que apunta, el cual se verá reforzado y "realizado" por la dinámica dominante en cuanto ésta sea sobredeterminada y cobre la relevancia que le es propia. El primer acontecimiento, del cual arranca la coyuntura de inicios de la década, se sitúa fuera del proceso salvadoreño, marcando un contexto internacional que va a ser decisivo para precipitar en El Salvador la importancia y la orientación de lo político. Se trata del triunfo de la revolución cubana, fechado el primero de enero de 1959. Éste va a ser más que un hecho histórico de repercusión mundial; representará una verdadera sacudida continental, tanto en América Latina como en Estados Unidos. La evolución de los acontecimientos relacionados con la revolución cubana a lo largo del año 1959 marcará poderosamente la siguiente década en todo el continente.

El movimiento armado en Cuba contra la dictadura de Batista había tenido, antes de su triunfo, tintes nacionalistas y democráticos que no hacían presagiar el carácter radical, antiimperialista y socialista que tomaría el proceso después de enero de 1959. De ahí que Estados
Unidos no se hubiera inquietado inicialmente ante la sorprendente campaña victoriosa de la guerrilla castrista en las montañas de la Sierra Maestra. Fidel Castro era presentado en la propia prensa norteamericana como un joven abogado idealista, lleno de patriotismo y de audacia política. Su lucha contra la dictadura, contra la corrupción y el atraso en la isla, parecía justa a los ojos de los periodistas que lo entrevistaron.

De ahí la sorpresa de la gran potencia estadounidense cuando el líder de la revolución cubana anunció un ambicioso programa de transformaciones radicales, que incluía una profunda reforma agraria, afectar propiedades de ciudadanos norteamericanos, así como las inversiones estadounidenses y los intereses de las empresas extranjeras. Washington creyó que, presionando a la revolución cubana, sus líderes abandonarían esa mezcla de ingenuidad y romanticismo que parecía inspirarlos y que se verían forzados a adoptar un rumbo realista y moderado. Al fin y al cabo, la isla dependía en un $90 \%$ de sus vínculos con el mercado norteamericano y su economía interna era totalmente dependiente de las inversiones, la tecnología y la materia prima estadounidense. El error de apreciación de Estados Unidos fue mayúsculo.

A cada medida de presión, Fidel respondía con sus propias contramedidas, en una escalada que muy pronto definió para Cuba un 
rumbo antiimperialista y orientado al socialismo. Ante las restricciones a su cuota de azúcar en el mercado estadounidense y las primeras medidas de bloqueo económico, más tarde el boicot total al azúcar cubano y el apoyo norteamericano a las actividades armadas contrarrevolucionarias, Cuba respondió expropiando las inversiones y las propiedades de los estadounidenses, nacionalizando sus empresas, suscribiendo con la Unión Soviética tratados comerciales para vender la totalidad de su azúcar a precios superiores a los del mercado mundial y asegurar el vital suministro de petróleo. Pronto seguirían acuerdos de asistencia militar soviética, hasta finalmente declarar a Cuba república socialista y adherirla a las diversas instancias del bloque comunista.

Estados Unidos había subvalorado el fenómeno político que tenía enfrente y su misma política prepotente había contribuido a acelerar y radicalizar la revolución cubana. Ante sus costas de la Florida, a escasas noventa millas, tenía ahora un régimen comunista que se alzaba desafiante y cuyo liderazgo parecía dispuesto no sólo a resistir, sino también a expandir su influencia en el continente latinoamericano. La revolución cubana se había convertido en pieza de importancia en el tablero mundial de la guerra fría, su contención y eventual eliminación pasaba a ser alta prioridad para los Estados Unidos.
La Administración de J. F. Kennedy diseñó una estrategia de doble vía para enfrentar el desafío cubano $y$, sobre todo, frenar el peligro de expansionismo cubano-soviético en el continente latinoamericano. Reconociendo la vulnerabilidad de toda América Latina a las ideas revolucionarias y al ejemplo triunfante de la experiencia cubana, el primer filo de su política iba dirigido a atender los problemas inmediatos de hambre y miseria, así como medidas que favoreciesen un camino al desarrollo económico de la región. De ahí el programa de la llamada Alianza para el Progreso, ALPRO. El otro filo, complemento del económico, era el componente militar. Se diseñó la "doctrina de seguridad nacional" en la que se definía el concepto de "enemigo interno" y se inició el adiestramiento en tácticas de lucha antisubversiva a los militares latinoamericanos.

La estrategia preventiva para aislar a Cuba y preservar al subdesarrollado continente latinoamericano del probable "contagio" revolucionario, motivó asimismo una revisión de Estados Unidos respecto su actitud frente a los regímenes autoritarios. El gobierno de Kennedy consideró que las dictaduras eran un factor que hacía de toda América Latina fácil caldo de cultivo de la agitación comunista. Consideró necesario favorecer procesos de democratización política, al tiempo que se procuraba profesionalizar a los ejércitos y prepararlos para enfrentar eventuales actividades subversivas. 
En el caso de El Salvador, los círculos de poder se mostraron especialmente sensibles al nuevo ambiente que predominaba en la Administración de Estados Unidos, así como al temor generalizado de que el modelo cubano pudiera encontrar eco y simpatía entre sectores populares del país. Una serie de iniciativas reflejan un proceso de apertura política que motivó que la nación entrara en una nueva dinámica. El régimen de dictadura, tras dos golpes de estado sucesivos, en octubre de 1960 y en enero de 1961, recomponía su perfil y se orientaba hacia una limitada democratización. La nueva Constitución de 1960 enmarcaba la dimensión de la apertura y sus límites. En 1961 se fundaba el Partido de Conciliación Nacional, PCN, el cual venía a sustituir al Partido Revolucionario de Unificación Democrática, PRUD, fundado en 1948 según el modelo del PRI mexicano. El nuevo partido oficial generaba estructuras partidarias permanentes más allá de las coyunturas electorales y se instrumentaba para ser parte de un sistema político de partidos que no había existido anteriormente.

Se creaban ahora partidos opositores a partir de los espacios de legalidad que se habían abierto. El incentivo fue que la nueva Constitución de 1960 establecía el criterio de la representación proporcional en la Asamblea Legislativa. Anteriormente, el partido mayoritario imponía la totalidad de diputados, lo que dejaba el órgano legislativo en las manos del partido oficial de turno. Se abrían ahora posibilidades de lucha parlamentaria, con lo que tenía sentido para las fuerzas opositoras constituir partidos y participar en las contiendas electorales. Incluso el proscrito y clandestino Partido Comunista buscaría la forma de hacerse presente en la competencia eleccionaria por medio de la fundación de partidos de fachada o por la infiltración de partidos legales ya constituidos, como fue el caso del Partido Revolucionario Abril y Mayo (PRAM) y más tarde del Partido de Acción Renovadora (PAR) y de la Unión Democrática Nacionalista (UDN).

El primer gran partido opositor que se constituyó fue el Partido Demócrata Cristiano (PDC) fundado el propio año 1960. Pronto sería admitido en la Organización Mundial de la Democracia Cristiana. La corriente socialdemócrata también se haría presente en El Salvador desde la fundación en 1965 del Movimiento Nacional Revolucionario (MNR). Junto con la filo-comunista UDN, el MNR y el PDC generarían una alianza electoral del conjunto de la oposición a fines de la década, la Unión Nacional Opositora (UNO), que tendría gran protagonismo en los años setenta.

Una minoritaria pero activa representación parlamentaria y sobre todo la victoria de la oposición en algunos municipios, en especial el triunfo en la alcaldía de San Salva- 
dor del candidato demócrata cristiano Napoleón Duarte, en 1964, configuraron un panorama diferente a la tradicional dictadura al hacer efectiva la presencia opositora y existir una verdadera competencia política en el marco de la nueva legalidad. La permisividad abría también en otros ámbitos, como el universitario y el sindical, nuevos espacios para la actuación de otras corrientes políticas y de pensamiento diferentes a la oficialista.

Las élites dominantes en El Salvador comprendieron que la reforma política no sería suficiente para contener el peligro de radicalización opositora o de contagio subversivo, si no se emprendía paralelamente un esfuerzo en la economía que atenuara las graves contradicciones sociales que atenazaban al país. De forma tal que la preocupación por la estabilidad política estaba a la base de las iniciativas que emprendería el gobierno en el terreno de la política de desarrollo económico. El entusiasta impulso que el régimen salvadoreño dio a la conformación del Mercado Común Centroamericano, MCCA, tiene que ver con aquella consideración política. En nuestro análisis interpretamos que es la dinámica política, como factor determinante, la que impulsa que la dinámica económica opere como factor dominante del período.

Ciertamente había habido con anterioridad a la revolución cubana iniciativas en el área centroamericana tendientes a establecer zonas de libre comercio. A lo largo de la década de los cincuenta se acordaron una serie de Tratados bilaterales entre los Estados de la región. El Salvador fue el único país que llegó a establecerlos con todos sus vecinos: en 1951 con Nicaragua y con Guatemala, en 1953 con Costa Rica y en 1957 con Honduras. En junio de 1958 se convenía el Tratado Multilateral de Libre Comercio e Integración Económica Centroamericana, para una validez de 10 años y que debía entrar en vigencia a partir del año siguiente. Costa Rica demoró su adhesión hasta septiembre de 1963.

La existencia de estos antecedentes, sin embargo, no debe llamarnos a engaño: se venía retrasando y complicando el proceso por las suspicacias que despertaba en Washington, que no veía con buenos ojos la posible atenuación de la dependencia que dicho proceso pudiera conseguir. La concepción de los gobiernos centroamericanos se inspiraba en los planteamientos de la Comisión Económica para América Latina, CEPAL, que postulaba por un desarrollo autónomo de la región, limitando las actividades de las empresas transnacionales y de las inversiones extranjeras. La CEPAL esperaba lanzar un modelo de "desarrollo hacia adentro" desde la ampliación del mercado y de la base productiva que la integración económica iba a generar. 
El "desarrollismo" cepalino pasaba por la industrialización mediante el Ilamado modelo ISI: industrialización por sustitución de importaciones. En principio se esperaba que la región cerrase sus puertas a productos manufacturados fuera de Centroamérica, de manera tal que el libre comercio dentro de la región fuera acompañado por una política proteccionista respecto productos foráneos. Estados Unidos venía entorpeciendo la puesta en ejecución de estos planes y no cambió de actitud sino cuando los riesgos que acompañaban el reciente triunfo de la revolución cubana los motivó a flexibilizarse. De todos modos, a cambio de su visto bueno y apoyo al proceso de integración, éste tuvo que renunciar a varios de sus componentes clave. El MCCA, lejos de poner restricciones a la operación de empresas multinacionales las iba a favorecer, en vez de controlar las inversiones de capital externo iba a estimularlas.
De tal modo que el proceso real de integración económica en Centroamérica resultó en una fusión entre los planteamientos centroamericanistas de la CEPAL y los intereses de los Estados Unidos en la región en un difícil equilibrio. La pregunta para muchos era si América Central podría alcanzar el desarrollo sin el apoyo de Estados Unidos, mientras para otros era a la inversa, si podría desarrollarse sin romper primero con la tutela y los vínculos de dependencia respecto la gran potencia del norte. Tal como aquí se analiza, el consenso que se alcanzó -y que permitió lanzar el experimento del MCCA- hay que verlo como una decisión política adoptada por el poder político. Fue la motivación política -y no tanto económica- la que hizo que Estados Unidos cambiara su anterior posición reticente, al igual que a los gobiernos centroamericanos los apresuró a aceptar.

\section{La dinámica económica}

Un ambiente de optimismo y esperanza acompañó la puesta en marcha de las medidas de reforma política y apertura democrática. Éste se vio reforzado con las iniciativas que se tomaron en materia económica. Todo parecía indicar que las élites dominantes ahora estaban decididas a enrumbar el país hacia un verdadero proceso de modernización que abarcara tanto la esfera de ejercicio del poder como la infraestructura económica. Entre la dinámica política determinante y la dinámica económica, que tendía a ser dominante, no había contradicción sino todo lo contrario. La segunda venía a reforzar y sustentar el efecto positivo de la primera.

Se recuperaba el discurso liberal -centrado en los ideales de progreso y modernización- que en el siglo pasado había inspirado las 
reformas que introdujeron el café en el país. Sólo que ahora de lo que se trataba era de lo contrario: de cómo salir de la dependencia al café, de cómo superar la debilidad de esta economía agroexportadora de monocultivo. Mediante el proceso de integración económica regional se esperaba que El Salvador no sólo consiguiera superar la crisis del modelo económico, evidente desde que los precios internacionales del café habían caído tras acabar la Segunda Guerra Mundial; también se tenía la expectativa de un despegue económico que le permitiera a la nación dar el salto hacia el desarrollo. De la mano del dinamismo económico se esperaba también alcanzar una mejoría sustancial en la situación social de las mayorías trabajadoras, incrementar los puestos de trabajo y reducir sensiblemente el desempleo y el subempleo, ampliar la cobertura educativa y de salud, generar un nuevo ambiente de tolerancia y apertura política que le diera estabilidad al régimen político y lo preservara de los peligros de la agitación comunista y de la acción subversiva. Las élites mostraban cierta sensibilidad social pero, sobre todo, preocupación política; pretendían tener una visión integral de la situación de subdesarrollo y atraso, pero principalmente reaccionaban como por instinto de supervivencia a los síntomas de crisis en el modelo de economía dependiente.

En este primer momento de la dialéctica -en que la dinámica económica llegaba a ser dominante por el impulso de la determinante dinámica política- predominaba la relación armónica entre ambas: la economía venía a ser el complemento necesario y conveniente de la política. No sería sino hasta en un segundo momento en que aparecería la tensión y contradicción entre ambas.

El capital salvadoreño se lanzó a la conquista de los mercados centroamericanos desde la precariedad de su base económica, pero con una considerable audacia y agresividad. Tuvo bastante éxito, en especial en la primera mitad de la década. Aparecía como el país que mejor estaba aprovechando el marco del MCCA. En realidad, toda la región hizo inicialmente una experiencia exitosa. En los años sesenta, Centroamérica alcanzó una tasa de crecimiento de la producción industrial del $9.6 \%$ anual, mientras el grado de industrialización (medido dividiendo el producto industrial por el Producto Interno Bruto, PIB) pasaba del $13 \%$ en 1960 al $16.7 \%$ en 1970. De parte de El Salvador, este mismo índice saltaba del $14.6 \%$ al $18.9 \%$ en el mismo período. ${ }^{11}$ El nivel de consumo de toda la región alcanzó los 1,653 millones de US\$ en 1963 y en 1969 ascendía a los 2,590.5 millones de US\$. El poder de compra centroamericano se incrementaba en un $12 \%$ anual durante los primeros cinco años y continuó subiendo, pero a un menor ritmo del $7 \%$ anual a lo largo del siguiente lustro. 
Como dijimos antes, el punto de partida era totalmente precario. A inicios de la década, en El Salvador todavía predominaba el artesanado en las actividades industriales y el número de fábricas era muy reducido. Se menciona que únicamente 39 de ellas -de las que 22 eran de bebidas- sobrepasaban el millón de colones de producción anual para 1950. ${ }^{22}$ Una década más tarde, en 1960, las exportaciones salvadoreñas dependían aún en un $62.87 \%$ del café. El proyecto del MCCA implicaba que la acumulación originada en el café debía trasladarse a otros rubros -industrial y agropecuario de productos no tradicionales de exportación- para su inversión. Se consiguió muy limitadamente.

La caña de azúcar y el algodón venían acompañando como productos tradicionales de exportación al café, a los que se agregó -con un menor peso- uno no tradicional: el producido por la industria camaronera. La incipiente industrialización se apoyaba en ellos. En 1971, después de la década desarrollista, El Salvador tenía tres ingenios azucareros, cuatro beneficios de algodón, 85 de café y otras 115 despulpadoras. Entre todos suponían el $39.8 \%$ del empleo industrial.

El sector agropecuario había seguido pesando sobre los otros sectores económicos. En realidad las ramas industriales que se desarroIlaron en la década de los sesenta eran todas ellas de industria liviana. En primer lugar se ubicaba la rama de la alimentación que, junto a la de bebidas, aportaba más de la tercera parte del producto industrial. Seguía la de vestidos, que sumada a los textiles representaba una cuarta parte del mismo. Más atrás se ubicaba la rama del calzado. Con mucha menor importancia cabe consignar la de productos químicos (farmacéuticos e insumos agrícolas) y la de derivados del petróleo (plásticos), la de aparatos eléctricos (electrodomésticos) y, por último, el tabaco. Las industrias relacionadas con la alimentación significaban el $38.4 \%$ de la industria nacional. La mayoría de industrias -un $66.6 \%$ de ellas- estaba ligada al sector agropecuario, del que provenían la mayoría de sus insumos. El café, el algodón y la caña de azúcar suponían el $51.6 \%$ del total de materias primas utilizadas por la industria centroamericana y el $76 \%$ de las de origen local.

Gran parte de los objetivos estratégicos del MCCA no se alcanzarían. Las importaciones de terceros países sólo disminuían de un 33.4\% en 1963 a un $28.5 \%$ en 1969 . El papel del capital extranjero, lejos de reducirse, se incrementaba. Mientras en 1959 la inversión extranjera directa en la región ascendía a 388.2 millones de US\$, para 1969 ésta había aumentado a 755.3 millones de US\$. Es decir, se había casi duplicado. Se diversificaba muy débilmente. Estados Unidos contri- 
buía en 1959 con un 90\% de capitales y en 1969 con un $80 \%$, siendo seguido muy atrás por las inversiones de Japón, Canadá, Alemania, Holanda, México y Colombia. Estos últimos dos países, "con intereses en la región", darían después -con España y Venezuela- un importante apoyo al proceso negociador. Un $45 \%$ de este capital extranjero era inversión industrial. En 1969 había 572 empresas extranjeras operando en la región centroamericana, de las que en un $72 \%$ su procedencia era norteamericana. El propósito principal -que era alcanzar el desarrollo, reducir la dependencia económica y el volumen de las importacionesno se lograba. En lugar de sustituir importaciones por producción propia, lo que ocurría en realidad era que se sustituían unas importaciones por otras. La industria ligera que se había generado requería de maquinaria, repuestos e insumos, que lejos de debilitar reforzaban la dependencia. Aumentaba el consumo y paralelamente la necesidad de importar nuevos productos manufacturados para el mercado local.

Esta limitada modernización económica fatalmente debía limitar asimismo la apertura política. Se cumplía el segundo momento de la dialéctica que hemos planteado, de modo que el factor económico imponía su dominación sobre el factor determinante o dinámica política. Para que ésta hubiera podido imponer su dominio, su impulso hacia la auténtica democratización, se hubiera requerido un cambio drástico de las relaciones en el poder económico. Pero esto no se dio. No hubo el surgimiento de una "burguesía industrial" que se enfrentara a la tradicional "oligarquía cafetalera". Defender esa idea es defender un mito. Quienes incursionaron en las actividades industriales en su mayoría provenían de las filas de los terratenientes. Tampoco abandonaron sus propiedades ni sus intereses agropecuarios; los nuevos empresarios industriales seguían siendo cafetaleros, cañeros, algodoneros... Unos pocos provenientes del capital comercial se sumaron a este sector manufacturero, sin abandonar ellos tampoco su actividad en el sector terciario.

No sólo esto: el fortalecimiento del sector bancario provenía de familias tradicionales de la propiedad agraria que habían expandido sus negocios al sector industrial y comercial. Al revisar la exhaustiva información que ofrece el Dr. Eduardo Colindres en su libro, se identifica fácilmente la repetición de nombres en las listas de miembros de Consejos de Administración y Juntas Directivas. Puede ahí establecerse una radiografía del capital salvadoreño, de sus redes y conexiones mutuas. No hay una diferenciación de la clase dominante, no son identificables fracciones ni grupos rivales: lo que hay es repetición de apellidos en los órganos directivos del capital agropecuario (Asociación Cafetalera, Cooperativas Azucarera y Algodonera) y del capital industrial, 
comercial y financiero (Asociación Salvadoreña de Industriales, Cámara de Comercio e Industria de El Salvador, Juntas Directivas de los principales bancos privados del país).

No había una verdadera contradicción entre empresarios "modernos" y terratenientes "atrasados", entre industriales y propietarios agrarios. No se producía un recambio en la clase dominante, sino un simple proceso, aunque acelerado, de renovación. A la par de algunos "nuevos ricos" aparecían los "viejos ricos" de siempre, millonarios convertidos ahora en multimillonarios. Mientras con la industrialización algunos aprovecharon para aumentar su fortuna, en cambio familias antes acaudaladas aparecían ahora "venidas a menos". En resumen, en la década de los sesenta la tradicional oligarquía económica del país no es desplazada del poder económico, aunque sí transformada por el proceso de modernización. Quienes se adaptan a los nuevos tiempos pertenecen a la oligarquía tradicional, a la que se suma un grupo de empresarios que ascienden socialmente y se integran a aquélla. Los poderosos de siempre no sólo no han perdido su posición, ahora se hacen más poderosos que nunca, con un poder todavía más total y excluyente. Su incursión en el sistema bancario y su reciente dominio del capital financiero, su control del crédito, expresa la concentración del poder económico que se ha producido y que se ha incrementado, a pesar de la ampliación que aparentemente se produce en las filas de la clase económicamente dominante.

Esta situación en la dinámica económica repercute sobre la dinámica política y limita sus alcances. El poder real no ha cambiado de manos, por lo que el poder formal va a reflejar esa realidad. Puede variar la forma de la dominación, pero no su contenido ni su carácter. En este segundo momento dialéctico queda claro que la apertura política no va a suponer una verdadera democratización, sino solamente permisividad. La posibilidad primera parecía abrirse con el golpe de estado progresista del 26 de octubre de 1960; se cerraba abruptamente con el contragolpe más conservador del 25 de enero de 1961.

De tal manera, el escenario político reflejará una ambigüedad fundamental: la oposición pasa a ser legal, pero no deja de ser perseguida, marginada, reprimida. Formalmente son fuerzas políticas legales; en realidad solamente "toleradas". Se pondrá en juego el poder local, permitiéndose que la oposición administre algunos municipios, siendo su límite de tolerancia máximo el reconocimiento del triunfo opositor en la alcaldía de la capital. Pero no se va a permitir su acceso al poder nacional, como se comprobará en elecciones presidenciales en las que el oficialismo recurre a tácticas intimidatorias y a la violencia para impedirlo. Algunos 
partidos opositores son prohibidos, con diversas excusas, antes o después de los eventos eleccionarios. La competencia política es, por lo tanto, más aparente que real. El PCN no había nacido para competir, sino para gobernar. De tal modo, la apertura política de los sesenta, aunque importante, no representa una ruptura respecto al pasado, sino la continuidad del mismo régimen. Cambia el sistema político pero se mantiene la dictadura militar.

Lo que en el fondo se sigue manteniendo es la estratégica alianza entre los militares y el poder económico. La clase dominante había cedido, desde la década de los años treinta, la administración del poder político al estamento militar, replegándose la oligarquía a su mundo de los negocios y dejando el ejercicio de la política y el mantenimiento del orden a la Fuerza Armada. Este fundamento del régimen quedaba ahora preservado mediante la variante de un partido oficial de nuevo tipo, con cierta base de civiles reclutados entre la clase media y sobre todo del sector de empleados públicos. El poder político se ejerce en clara representación y defensa de los intereses del poder económico. Este no ha sido verdaderamente transformado en la dinámica económica generada en los sesenta, por lo que -consecuentemente- tampoco lo es en esencia el poder político.

El autoritarismo prevaleciente tras la fachada de la democratiza- ción aparente quedaría más patente con la creación de organizaciones afines al partido oficial que, sobre todo en el área rural, ejercían funciones de control y amedrentamiento de la población. Así, la tristemente célebre Organización Democrática Nacionalista, ORDEN, fundada por el entonces coronel Medrano a mediados de los sesenta, y que aterrorizó por muchos años la campiña salvadoreña. Antecedente de las redes de escuadrones de la muerte, ORDEN servía de estructura de reclutamiento en el campo, pero cuando convenía actuaba como fuerza de choque, al modo fascista, para agredir grupos cooperativos o sindicalistas.

Los límites políticos de la apertura quedaban claramente de manifiesto en la legislación sindical. Los sindicatos quedaban reconocidos en el nivel constitucional, pero solamente como fenómeno urbano. La sindicalización y en general todo tipo de organización en el campo quedaban prohibidas por la Constitución, así como los sindicatos de empleados públicos. La ambigüedad se daría ahora a la inversa. Tales sindicatos eran ilegales, pero de hecho -dependiendo de la correlación de fuerzas- resultaban reconocidos y era con ellos que, tanto el gobierno como los terratenientes, se reunían y negociaban. Lo cual no impedía que en otro momento y circunstancia fueran nuevamente perseguidos desde el argumento de su ilegalidad. 
Todo ello no hacía sino agudizar la dinámica social que, como consecuencia de la doble frustración de las iniciales expectativas en la dinámica política y en la económica, no iba sino a acelerar la contradicción entre ambas. En medio del crecimiento económico y de la apertura política, no obstante, la dinámica social mostraba tensiones que agotaban las posibilidades reales del proceso y oscurecían su perfil optimista.

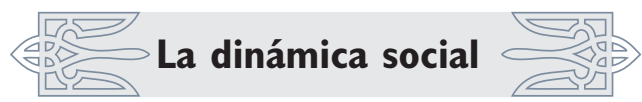

Producto de la dinámica económica hubo algunas transformaciones en la estructura de clases. El proceso de industrialización generó, lógicamente, una incipiente clase obrera fabril y, con ella, un impulso al movimiento sindical urbano. Paralelamente hubo un cierto crecimiento de las clases medias, por la misma demanda de las industrias de personal técnico y administrativo. Pero no deben sobreestimarse estas novedades.

La formación de una conciencia de clase en el caso del proletariado salvadoreño presentaba sus limitaciones, por tratarse de un sector de procedencia campesina reciente y además por el reducido tamaño que prevalecía en las empresas. La mayoría de establecimientos industriales en El Salvador de la época eran lo que se denomina pequeña y mediana empresa. Sólo el $22.6 \%$ eran fábricas con más de 50 empleados, mientras un $60.9 \%$ tenían entre 5 a 24 trabajadores. ${ }^{33}$ En el rubro "industrias varias" se ha consignado que para 1971 había un total de 1,003 empresas, que daban empleo a 26,931 trabajadores. Ese sería el "tamaño" de la clase obrera urbana en El Salvador, inferior al de una sola gran empresa en países desarrollados. La formación de un movimiento sindical tenía que enfrentar las lógicas dificultades por la dispersión que impone dicha estructura industrial, la cercanía del trabajador con el patrono y el paternalismo que predomina en empresas de pequeño tamaño. No obstante, ya había tradiciones de lucha sindical en El Salvador y éstas serían retomadas y revitalizadas durante los sesenta. Lo veremos posteriormente.

Hay que tomar en cuenta también al proletariado agrícola, que suponía el $39.8 \%$ de los trabajadores industriales. Sólo en los beneficios de café trabajaban 12,405 obreros, a los que se deben sumar los trabajadores en los beneficios de algodón, en las despulpadoras de café y en los ingenios de caña de azúcar. Al incluirlos, la dimensión total de la clase obrera salvadoreña ascendía a 40,455 trabajadores. Diversas formas organizativas se extenderían en el campo, siendo un caso especial el del Sindicato 
del Café, SICAFE, impulsado en los beneficios de la zona occidental del país.

Por el lado de la clase media hubo una ampliación, aunque limitada. Según el Anuario Estadístico de 1971 había en el país 6,402 empleados administrativos y 689 técnicos. Ni por su tamaño, ni por su dispersión, podía este grupo social ejercer el papel de "colchón social" que amortigua y suaviza las tensiones entre clases antagónicas, como se da en otros países. De ahí que desde el poder político se procurara apoyar la multiplicación de los pequeños propietarios, tenderos, comerciantes, pequeña burguesía en fin, que podía constituirse en una base social potencial. Y, desde luego, hubo una línea de agrandar el tamaño de la burocracia estatal como una forma de pagar favores políticos y para contar con una base de apoyo, leal y segura, entre la masa de empleados públicos. No obstante, un gremio específico daría la sorpresa con grandes movilizaciones en la segunda mitad de la década: el magisterio nacional. Lo abordaremos también más adelante.

A la vista de esta estructura de clases, no extraña que un grupo social que no constituye propiamente una clase, como son los estudiantes universitarios, se haya constituido en promotor y vanguardia de los movimientos de protesta. La Universidad Nacional, la única existente en la época, fue un centro de pen- samiento opositor y frecuente foco de agitación antigubernamental.

Aunque el proceso de modernización fue básicamente un fenómeno urbano y se efectuó más que nada en las ciudades, sobre todo lo referente a la industrialización, no obstante en la dinámica social presentó un gran protagonismo el campesinado salvadoreño. Si se examina bien el conjunto del diseño impulsado por el gobierno, no debiera extrañar. Es una cuestión de transferencia de recursos. El financiamiento de la industrialización no podía venir sino de la acumulación generada en el agro. En el fondo, el campo iba a financiar la modernización económica de la ciudad. En esa lógica era de esperar que los agricultores iban a resultar afectados negativamente, al menos durante una fase inicial.

Una serie de factores vinieron a sumarse a este fenómeno, agravando la situación social del campesino salvadoreño. En primer lugar, hay que mencionar las expectativas que se levantaron. Era lógico en un país con una fuerte desocupación estructural. Los datos de que se dispone para 1961 indican que mientras la mano de obra requerida en el campo era de 208,136, ascendía a 484,389 la disponible. La diferencia señala un excedente de 276,253 trabajadores, es decir un $56.5 \%$ de la fuerza de trabajo total. ${ }^{44} \mathrm{El}$ anuncio de las nuevas iniciativas económicas y de la apertura de fábricas en 
las zonas urbanas fue recibido por la población campesina como la feliz noticia de que se abrirían puestos de trabajo. Pero ya hemos visto antes que su cantidad nunca fue tan grande. No llegaría ni a la décima parte del excedente de mano de obra que presentaba el agro. La industria no iba a resolver el problema del desempleo en El Salvador. Pero no se sabía todavía, ni el campesino tenía por qué saberlo.

Cuando la situación es desesperada, la gente se agarra a cualquier cosa que signifique una esperanza. Es lo que ocurrió en los sesenta. Se generó un espontáneo movimiento migratorio interno del campo a la ciudad que superaba en mucho la capacidad urbana de ofrecer empleo, y también su capacidad de ofrecer albergue, sobre todo tratándose de gente pobre. En poco tiempo, la capital se Ilenó de colonias ilegales, zonas marginales y tugurios. Miles de familias campesinas improvisaban sus champas donde podían. Se las encontraba por todos lados, a la orilla de las quebradas, en predios baldíos. En plena euforia del crecimiento económico y de la modernización se daba la paradoja de que la capital se veía invadida por la miseria. Siempre la hubo, pero antes no era tan evidente porque estaba lejos, menos visible. Para algunos, era parte del paisaje rural, del tipismo.

A la secular pobreza de los campesinos se agregaba ahora el sentimiento de frustración, sin que ello frenara la llegada de nuevos miles a engrosar las filas del desempleo urbano y de "la rebusca" de la mera sobrevivencia. La dinámica social contradecía el discurso oficial, optimista y bienintencionado, que pretendía que de la mano del desarrollo venía la redención de las masas pobres. "La única forma de conquistar la libertad, la seguridad y la paz social, es erradicando la miseria", había anunciado solemnemente la Proclama de la Fuerza Armada del 5 de febrero de 1961, pocos días después del golpe de estado de enero. También anunciaba una "reforma social" que debía incluir fuentes de trabajo, empleo en el campo, vivienda rural y urbana, sistema tributario progresivo, educación técnica, salud y seguridad social. ${ }^{55}$ "El camino al infierno -decía sabiamente Dante- está empedrado de buenas intenciones". El Salvador confirmaría esta verdad.

En segundo lugar, lo que vino a tensionar gravemente la situación social en el campo fue la destrucción de la economía de subsistencia de las mayorías campesinas. Ha sido tradicional la siembra de granos básicos. De ellos depende el campesino para su dieta alimenticia $y$, en años de buena cosecha, le permite obtener alguna entrada monetaria vendiendo los excedentes. Se registró un dramático descenso en relación con la década anterior. Mientras en 1950 se producían 2.4 quintales de maíz por habitante, 
este promedio había caído en 1961 a sólo 1.3 quintales. De arroz se cosechaban en 19500.23 quintales, en 1961 tan sólo 0.11 por habitante. Respecto al frijol, las cifras son todavía más elocuentes: de 0.33 en 1950 se bajó a únicamente 0.09 quintales por habitante en 1961. De ser un país con superávit, El Salvador había pasado a tener la necesidad de importar granos básicos. Las consecuencias eran, para muchas familias campesinas, dramáticas.

Esta crisis en la seguridad alimentaria era efecto directo de la llamada modernización. Dicho de manera más precisa, era la consecuencia de la penetración del capitalismo en el campo. Se había expandido la ganadería como actividad capitalista agropecuaria cuyo destino era el mercado. Alrededor de medio millón de hectáreas estaban a inicios de la década de los sesenta dedicadas a una ganadería primitiva que pastaba libremente. El $67 \%$ de las tierras en fincas mayores de 50 hectáreas se habían convertido en tierra de pastos. Esas fincas de gran tamaño, que suponían tan sólo el $2 \%$ del total de propiedades agrarias y acaparaban más de las dos terceras partes de la tierra con vocación agrícola, se habían pasado al negocio de la carne, expulsando a gran parte de los arrendatarios y colonos. La explotación extensiva de la ganadería sustituía la explotación intensiva de granos básicos. Era la ruina de los campesinos pobres.
Al efecto nefasto de la ganadería se sumaba el de otra explotación de tipo capitalista: el algodón. Quienes entraban a este negocio a menudo ni siquiera adquirían el terreno sino que se limitaban a alquilar la tierra, en una operación típicamente empresarial, donde lo decisivo era poseer el capital o el acceso al crédito. Si más adelante, agotado el suelo o envenenado de tanto pesticida, la productividad bajaba, simplemente dejaban el lugar y rentaban en otra parte. La banca se mostró generosa con los algodoneros, al punto que éstos pronto estuvieron en posición de fundar sus propios bancos. ${ }^{66}$ También el gobierno fue generoso: dedicó una buena cantidad de fondos públicos en construir la carretera litoral para rentabilizar y volver atractiva la inversión en plantaciones de algodón. Dejaba jugosas ganancias: el bajo nivel de salarios hacía competitiva la fibra de algodón aún en períodos de baja en los precios internacionales, con la ventaja adicional de que Japón y Europa premiaban la limpieza del algodón cosechado a mano, como se hacía en las condiciones del subdesarrollo nacional en contraste con los medios mecánicos utilizados en otros países.

Se generaron efectos paradójicos. En 1961, el $19.1 \%$ de la tierra era trabajada en régimen de arrendamiento. El tamaño promedio de las parcelas arrendadas era de unas dos manzanas. El éxito del algodón cambió las prioridades de los terra- 
tenientes. Ahora preferían alquilar a los algodoneros. Al campesino se le empezó a exigir el pago en efectivo y por adelantado, mientras antes era usual que pagara después con una parte de la cosecha. Los pequeños arrendatarios resultaron masivamente expulsados.

El tercer factor que contribuyó seriamente a agravar la situación social en el campo fue resultado directo de una medida gubernamental. Como parte de su política reformista y de su proyección social, el gobierno decidió en 1965 promulgar con efectos para el área rural la Ley del Salario Mínimo. Se fijaba éste en dos colones con veinticinco centavos diarios, lo que parecía iba a representar una buena mejoría para los campesinos, puesto que venían cobrando un colón con cincuenta centavos por día de trabajo, más los tres tiempos de comida. Sin embargo, en varios lugares los trabajadores agropecuarios se mostraron insatisfechos pues los patronos se negaban ahora a incluir la alimentación como parte del pago y les cobraban por la comida más de los setenta y cinco centavos de aumento que suponía el nuevo salario mínimo.

Pero las repercusiones más graves se dieron con respecto a los colonos. En 1961, un $24.6 \%$ del total de la tierra en fincas se explotaba por el sistema de colonato. Con la nueva ley, que obligaba al finquero a cancelar a cada trabaja- dor el salario mínimo, se produjo una expulsión masiva de colonos. Las buenas intenciones del gobierno tenían un efecto contraproducente e inesperado.

En resumen, tanto como consecuencia de la modernización y el desarrollo económico que impulsaba la dinámica económica, como por efecto de la dinámica política por la que el gobierno imponía su reformismo paternalista, vino a agravarse la situación social para gran parte de la población rural. La dinámica social entraba en conflicto con las dinámicas política y económica. El punto débil del proyecto desarrollista del país estaba en esta estructura de propiedad y tenencia de la tierra, como lo ponía de relieve la creciente conflictividad social que venía generándose en el campo. Una vía consecuente al desarrollo no podía darle la espalda a esta problemática. La alternativa más plausible era emprender una profunda reforma agraria que transformara las estructuras de acceso a la tierra, dignificara la situación social del campesino y creara las bases para su mejora acrecentando su capacidad de consumo. Eso habría suavizado las tensiones y creado una demanda solvente para generar un mercado interno de mayor tamaño, como base para el desarrollo real de los sectores industrial y de servicios.

De hecho, en Honduras se promulgó una reforma agraria a fines 
de la década, mientras el gobierno salvadoreño -tras el desastre del MCCA- convocaría en 1970 a un Foro de Reforma Agraria. Demasiado tarde. Se abordaba al término de esta experiencia lo que debía haberse planteado desde un principio. La reforma agraria resultaba un paso ineludible para cualquier intento de despegue hacia el desarrollo. Pero ésta no podía emprenderse sino enfrentando las estructuras del poder económico. La dinámica social generaba un tensionamiento entre el poder económico y el político. Este último tenía que tomar partido, o con los poderosos, o a favor de los humildes. El espejismo de una prosperidad y progreso de toda la nación, que llegara a todos los salvadoreños, tendía a desvanecerse ante la realidad conflictiva que mostraba la dinámica social. Se anunciaba la dialéctica dramática que presidiría el proceso en las etapas siguientes.

Al no darse soluciones, se comprende la magnitud de los movimientos migratorios de la época. A los incentivos, más ilusorios que reales, que ofrecía la industrialización urbana se agregaba una situación rural insostenible para muchas familias campesinas. Una vez puestas en movimiento, ya no iban a regresar a la desesperanza de la que huían. Si no hallaban posibilidades de vida en la ciudad, simplemente seguirían los caminos de la migración al exterior. Era una opción: escapar del país. La emigración se constituía en una válvula de escape, no sólo individual sino nacional.

\section{Dialéctica entre las tres dinámicas}

En 1965 había en Honduras más de cien mil salvadoreños. En 1969, cuando se dio la guerra entre los dos países, la cifra probablemente pasaba del doble. La mayoría estaban dedicados a labores agrícolas. Se tienen datos de 1960: en esa fecha había en Honduras 108,581 personas en ocupaciones ilegales, en su gran mayoría salvadoreños. ${ }^{77}$ Otros se tomaron tierras ejidales, que constituían el $33.9 \%$ del total de tierra en Honduras. Para el campesino salvadoreño, la situación en Honduras ofrecía oportunidades inimaginables en El Salvador. A la pequeñez de su territorio -unos 22 mil kilómetros cuadrados- unía una fuerte densidad demográfica, correspondiente a una población de 3.3 millones para el año 1969, mientras Honduras tenía comparativamente un inmenso territorio -112 mil kilómetros cuadrados- para una población relativamente pequeña de 2.5 millones. Esto explica que muchas familias salvadoreñas, que huyendo de la miseria llegaban -como se dice- "sin más que la ropa puesta", rápidamente progresaban en Honduras. Sobraban los terrenos baldíos y no había un control estricto de la ocupación de la tierra como en El Salvador. Pronto estaban comer- 
ciando en pequeño sus cosechas, ahorraban y, en pocos años, muchos habían abierto tienda y se habían convertido en pequeños comerciantes. Todo esto fortalecía el mito de "la laboriosidad del salvadoreño", que era consecuencia de los hábitos adquiridos en la difícil lucha por la sobrevivencia propia de la misma sobrepoblación. También levantaba lógicamente envidias entre la población local, que no podía ver con buenos ojos la rápida prosperidad de los recién llegados. Se trata desde luego de "pueblos hermanos". Pero no excluye -como sabiamente enseña la Biblia- que puedan surgir rivalidades entre hermanos.

Antes de que se diera la campaña gubernamental contra los salvadoreños y su expulsión masiva de Honduras, que fue el detonante básico para la confrontación bélica entre los dos países, la fuerte emigración venía sirviendo para aliviar las tensiones por la tierra en suelo salvadoreño. También México y Guatemala recibieron gran cantidad de migrantes salvadoreños $y$, en menor cantidad, Estados Unidos y Nicaragua. Lamentablemente no hay datos fiables de estos flujos migratorios que se daban mayoritariamente de manera ilegal. No había autoridad migratoria ni policía fronteriza capaz de detenerlos. La fuerza que los empujaba era la misma situación insostenible de la estructura de la propiedad de la tierra en El Salvador.
El $63 \%$ de la población rural carecía de tierras. Es decir, unas 170 mil familias de un total de 269,105 familias campesinas. El $91.4 \%$ de propiedades eran minifundios con menos de 3 manzanas a los que correspondía menos del $22 \%$ de la superficie, mientras en el otro extremo casi el $38 \%$ de terreno era acaparado por 1,027 latifundios de más de 500 manzanas. Las propiedades a partir de 100 manzanas acumulaban el $58.5 \%$ de toda la tierra apta para el cultivo. La economía del café se beneficiaba de la abundante mano de obra disponible en todo momento y a muy bajo costo. Pero a largo plazo, la injusticia de esta estructura social y la precariedad de vida que imponía a las mayorías terminarían por pasar su factura histórica.

La coyuntura especial que se abrió durante la década de los años sesenta, con su cúmulo de expectativas favorables y de amargas decepciones, con la brusca agudización de las adversas condiciones de vida en el campo para una gran parte de la población -por las razones que hemos señalado anteriormente- precipitó el protagonismo del campesino.

Recapitulemos ahora lo que hemos venido planteando desde el punto de vista teórico y que es el enfoque que puede ahora auxiliarnos para el análisis. Hemos planteado cómo, en un primer momento, una dinámica que ejerce de 
factor determinante concreta en otra el papel de factor dominante. En nuestro caso se trata de la dinámica política que vino a determinar que fuera la dinámica económica la que asumiera el rol de factor dominante del período.
Dinámica política

Las iniciativas económicas vinieron a reforzar y apoyar la voluntad política que buscaba una democratización limitada o apertura del sistema con la intención de desactivar las tendencias confrontativas que las repercusiones continentales de la revolución cubana hacían razonablemente presagiar. Pero pronto surge la contradicción: desde el ámbito económico se dan ciertas prioridades por las que el desarrollismo previsto beneficia más a unos sectores que a otros, la estrategia supuestamente nacional se revela como parcial y parcializada. Los intereses económicos empiezan a confrontar y someter a la dinámica política, el factor dominante se vuelve contradictorio hacia el factor determinante, se ha vuelto en la negación del mismo, de forma que la dinámica política ha generado su propio opuesto.

Desde la relación entre ambas dinámicas, que se ha vuelto ahora plenamente dialéctica, se comprende la entrada en escena de un tercer elemento. Se trata de la dinámica social que viene siendo determinada en primera instancia por la económica y que por ella va a cobrar un relieve que no había tenido anteriormente. Refuerza la parcialidad de aquélla, reforzando la contradicción con la presunta universalidad de la dinámica política. Niega de tal manera la viabilidad de esa política populista, no interesada y de pretensión nacional, tensionando al límite sus posibilidades.

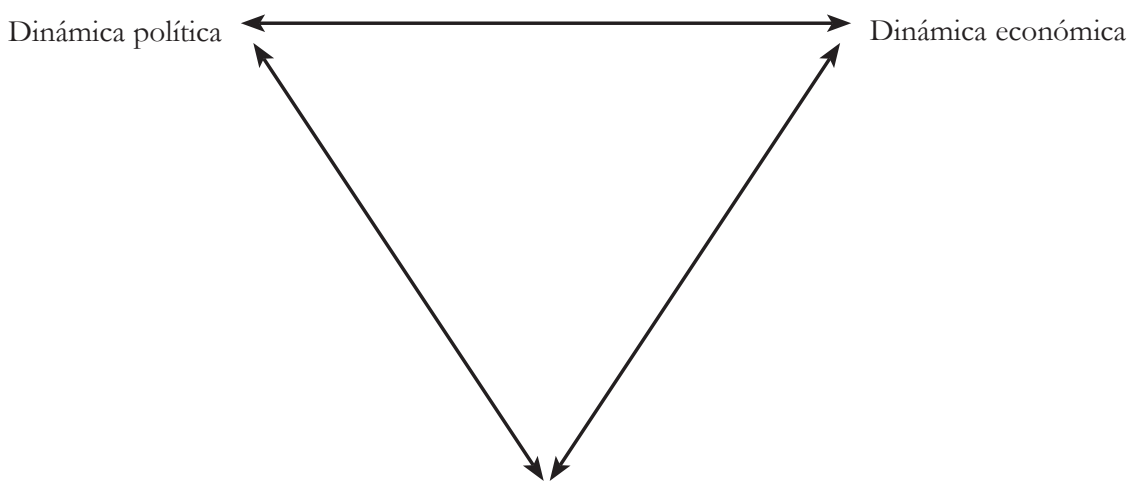

Dinámica Social 
Al término del período se comprenderá mejor que ha sido la conflictividad social generada por esta triple relación dialéctica la que se ha impuesto a la dinámica política, así como a la económica, y que al negarlas muestra la que era su verdadera esencia: clasista y demagógica. Pero eso no quedará patente sino hasta al finalizar este período, cuando la tríada dialéctica ha dado ya de sí todo lo que podía dar. Antes no está clara la mentira que se esconde tras la voluntad desarrollista y modernizadora de la élite, ni tenemos por qué sospechar que ésta tuviera todo claro desde el principio. Es lo más probable que haya habido mucho de credibilidad y convicción en la buena intención del inicio, aunque la objetividad de las cosas se impondrá sobre las conciencias -incluidas las de los dirigentes-, de manera que el programa bienintencionado termina derivando en un discurso cínico. El período tendrá entonces dos lecturas diferentes.
La primera lectura que podemos hacer desde la propuesta teórica que planteamos es la que sugiere la dinámica dominante, situada en el vértice superior derecho del triángulo que representa la tríada dialéctica del período. Ésta es la dinámica económica o dicho de manera genérica "lo económico". Es decir, el conjunto de iniciativas, acontecimientos y transformaciones acaecido en esa esfera concreta de la actividad social, que es el mundo de la economía. Desde esta perspectiva, la década de los años sesenta en El Salvador se presenta como un período dominado por el optimismo de las proyecciones económicas que asume el país y por un objetivo crecimiento económico que se refleja en el aumento del PIB, de los niveles generales de consumo, en las cifras de exportaciones, etc. Es una época de aparente bonanza así como de lógica esperanza en todo el potencial y la capacidad del país en ir superando los retos del atraso y de la situación del subdesarrollo.

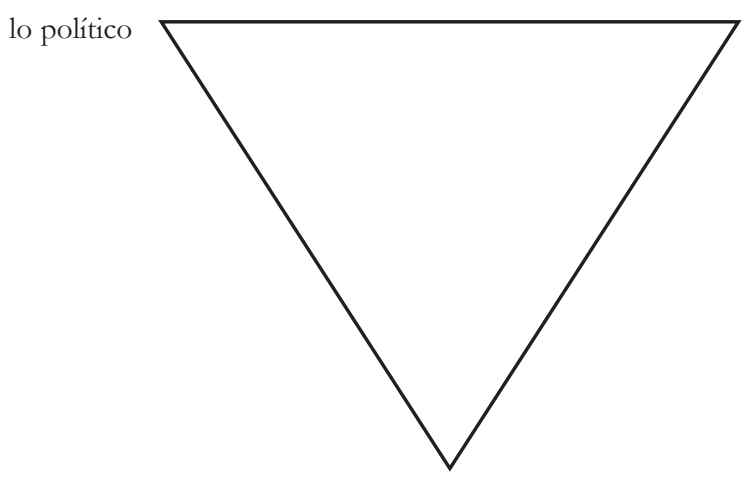

lo económico

lo social 
La segunda lectura se fija en la dinámica resultante, es decir, en el vértice inferior donde nos aparece "lo social" en oposición dialéctica con las dos dinámicas anteriores, que están en los vértices superiores del triángulo. Desde este elemento síntesis o, dicho con mayor propiedad, "negación de la negación" o "factor resultante", la interpretación indica lo que estaba gestándose a lo largo del período en cuestión. Es una lectura complementaria, pero sobre todo, antitética de la anterior. La década de los sesenta, leída desde esta tercera dinámica, aparece como el tiempo de la gestación de la crisis social, caracterizada por su alta conflictividad.

Ambas lecturas son ciertas, las dos ofrecen verdad sobre esta etapa del proceso histórico salvadoreño, pero desde perspectivas diferentes. La primera nos habla más de cómo fue vivido ese tiempo, de cuál era el "signo de los tiempos" que moldeaba las conciencias y las expectativas. La segunda, en cambio, nos refiere sobre su conclusión, nos conduce hacia el período inmediato posterior, nos da elementos sobre la conciencia surgida en el momento del agotamiento del período y de su superación. Este último es clave a fin de comprender el encadenamiento con las siguientes etapas del proceso. Es el "signo de los tiem- pos" percibido en su movimiento hacia lo nuevo, captado como esencial negación a lo que trataba de afirmarse en su momento. Representa a dicho "signo" en el proceso de negarse a sí mismo. Todo lo cual queda representado en el enigma y la sencillez de esta figura de triángulo, donde cada vértice está en tensión con los otros, y se desequilibra en un movimiento hacia abajo, adonde apunta en sensación de movimiento.

Desde la segunda lectura que se ha propuesto, la atención debe ponerse en los contenidos y la evolución de la dinámica social. Ésta va configurándose como crisis social, la cual tenderá a politizarse. O sea, el movimiento dialéctico no se detiene en la dinámica social considerada como "resultante". Lo es solamente con referencia a esta fase concreta de la historia del país, pero "resultante" en modo alguno debe entenderse como punto final al cual se llega, deteniéndose ahí el movimiento. La dialéctica histórica lo sobrepasa y deja en el camino, como un simple momento por el que ha transitado. Podemos adelantarnos en nuestra exposición para mostrar ese nuevo horizonte que se empezará a hacer visible desde la segunda mitad de la década. El esquema presenta la siguiente figura:
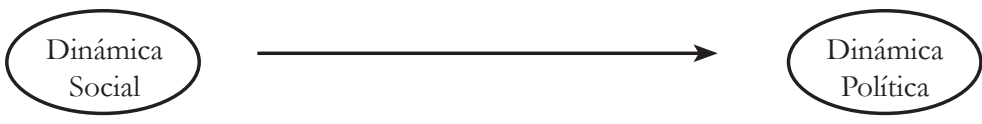
En la misma se muestra cómo lo social -que aparecía como "dinámica resultante" en la tríada dialéctica comentada anteriormente- tiende a su vez a constituirse en la "dinámica determinante" en un momento posterior, condicionando que otra esfera de la actividad -en este caso lo político- tome el papel de "dinámica dominante" en la fase siguiente. Por decirlo así, la dinámica social es punto de llegada y a la vez punto de partida hacia una nueva tríada dialéctica. Es lo que en la dialéctica tradicional se conoce como el paso de la "síntesis" a su transformación en nueva "tesis", que a su vez genera su "antítesis".

De tal manera, la década de los sesenta que venimos examinando queda resumida desde el análisis dialéctico en una figura que completa el triángulo que inicialmente habíamos propuesto, en la cual aparece ya este cuarto elemento como un nuevo vértice. De forma complementaria al triángulo invertido, que era nuestra figura anterior, debe consignarse este paralelogramo con forma de rombo recostado sobre uno de sus lados. En realidad, compuesto por dos triángulos inversos:

lo político

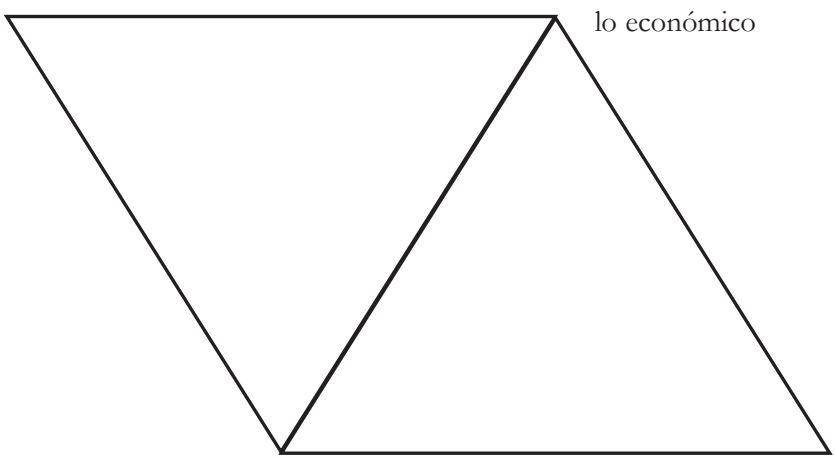

lo social

lo político

Vamos ahora a tener que considerar la segunda parte del rombo, el triángulo que apunta hacia arriba, que constituye la segunda fase del período que venimos analizando.

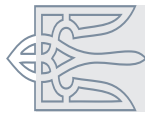

\section{La gestación del resultado del período: la alta conflictividad social}

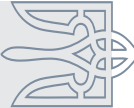

Como decíamos antes, poncontenidos y la evolución de la gamos ahora la atención en los dinámica social. En esta segunda 
fase del período -representada por la figura del triángulo que compone la parte derecha del rombo o cuádrupla dialéctica- debe verse "lo social" considerado como factor dominante, pues es ése el segundo elemento de la tríada, aunque lo sea únicamente durante este momento dialéctico intermedio.

Dinámica social

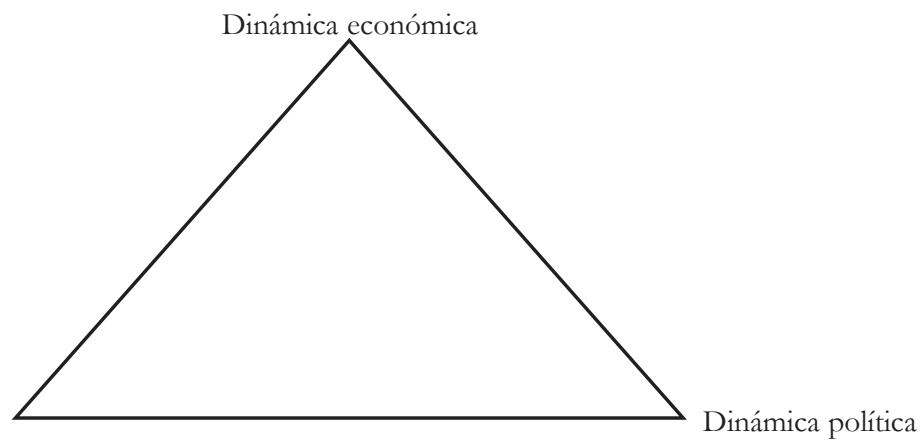

Pues bien, además de la conflictividad del campesinado, de la que ya hablamos anteriormente, aparecerá la crisis en la ciudad. Aunque la crisis rural tiene la mayor gravedad, tanto por la dimensión demográfica que abarca como por su agudización -y, de hecho, es la dinámica que precipitará el choque con Honduras, provocando el derrumbe de todo el modelo desarrollista-, no debe dejarse de lado la crisis social urbana. Por ser la ciudad el lugar donde se concentra el poder -en especial, la ciudad capital-, las repercusiones de cualquier trastorno social son inmediatas y a menudo de mayor trascendencia. En este sentido, tendrá que ser importante tomar en consideración las actuaciones del movimiento estudiantil-universitario, obrerosindical y gremial-magisterial. Los tres se mostraron activos y tuvieron bastante que ver con las tendencias a la politización de la dinámica social durante los sesenta.

Dediquemos primero unas palabras a la Universidad Nacional y a su papel protagónico en esa época. Es un tiempo en el que, en el ambiente de apertura que predomina, se va a dar una democratización del campus universitario. En primer lugar, por su composición social, que hasta entonces había sido bastante elitista. Empieza a cambiar a impulsos de los propios estudiantes y de algunos docentes. Según datos que cita Víctor Valle, en 1963 había únicamente 3,200 estudiantes universitarios, y en el plazo de tan sólo cinco años se había más que duplicado la cifra, pasando a ser 6,500 alumnos en 1965, incluidos unos 400 de extracción popular que estaban becados. En el mismo lapso 
de tiempo, la Universidad pasó de 60 profesores contratados a tiempo completo, a contar con 350 docentes de dedicación plena.

Relacionado directamente con lo anterior, hay que señalar lo más decisivo: el proceso de politización de la Universidad. Por su misma naturaleza había sido tradicional centro de inquietudes políticas. En esta coyuntura, esto se profundiza y radicaliza, haciendo que el alto centro de estudios pase a ser símbolo y catalizador del movimiento opositor.

En las tradiciones de lucha opositora universitaria hay que recordar el papel jugado en la caída del general Hernández Martínez, retirado del poder en 1944 tras las "heroicas jornadas de abril y mayo", cuando los universitarios convocaron a la población a la "huelga de brazos caídos" y fueron la vanguardia de la resistencia contra el dictador. En el derrocamiento de Lemus, el presidente impuesto por el partido oficial de turno, otra vez ha habido movilización universitaria tras reiteradas intervenciones represivas de la Policía Nacional, pese a las protestas del rector de aquél entonces, Napoleón Rodríguez Ruiz. En el gabinete de gobierno que se instala tras el golpe del 26 de octubre de 1960 que depuso al gobernante participan varios universitarios $y$ en la Junta Cívico Militar se integra Fabio Castillo, quien más tarde fue rector del Alma Mater. En las frau- dulentas elecciones de 1962, en las que el coronel Rivera es candidato único, nuevamente "la U", como se la conoce, está activa en las protestas opositoras. En tono festivo, el gremio estudiantil aglutinado en AGEUS, la Asociación General de Estudiantes Universitarios Salvadoreños, hace la presentación de su propio "candidato presidencial" en el Parque Libertad: Ilevan un burro vestido con el uniforme militar $y$ los galones de coronel. Con un cartel se promocionaba al invitado a competir con el coronel Rivera: "Este burro es coronel, este coronel es burro."

El humor político caracteriza casi toda la actividad propagandística y crítica de los universitarios en esa época, que encuentra gran eco entre la población trabajadora, que aplaude las burlas del "desfile bufo" o la mordaz ironía de la revista estudiantil La Jodarria". En su redacción participan algunos que después serán dirigentes comunistas y de las organizaciones revolucionarias, por ejemplo, Jorge Arias Gómez y Roque Dalton. Un joven Schafik Hándal, quien después será por largos años secretario general de los comunistas salvadoreños y dirigente del FMLN, en ese tiempo es dirigente estudiantil y colabora en la organización del FUAR, Frente Unificado de Acción Revolucionaria. Su accionar es también sobre todo propagandístico, por ejemplo, la pinta de los muros de la Embajada de Estados Unidos el propio día de 
la toma de posesión de Rivera. Junto a estas tendencias más radicales, la demócrata cristiana es considerada en la Nacional "la derecha". Es el caso de la Federación Revolucionaria Universitaria Social Cristiana, que dirige Rubén Zamora, quien después llegará a ser dirigente del PDC y más tarde del opositor Frente Democrático.

En 1964, las máximas autoridades universitarias viajan a la Unión Soviética y regresan con un acuerdo de cooperación académica con la Universidad de Lomonosov. El rector es Fabio Castillo y el vicerrector Guillermo Manuel Ungo, quien un año después funda el socialista Movimiento Nacional Revolucionario. En las elecciones de 1967, participa la izquierda a través del PAR, Ilevando como candidato presidencial al rector de "la U", Fabio Castillo. El régimen le concederá haber obtenido 77 mil votos. Mientras tanto la democracia cristiana llevaba de candidato a Abraham Rodríguez. Se impone el general Fidel Sánchez Hernández, candidato del PCN, partido que realizó sus propias elecciones internas, entre ocho precandidatos, imponiéndose al final el preferido por el gobernante de turno.

Será ésta de 1967 la última elección en que la oposición irá por separado. Se va a dar la confluencia y el acuerdo político entre corrientes político-ideológicas tradicionalmente enfrentadas nacional e internacionalmente. La Universidad Nacional ha contribuido de forma indirecta a esta concertación opositora: casi todos sus líderes se conocen desde su época de dirigentes estudiantiles en la Universidad. La casi totalidad hizo su aprendizaje político en el seno del movimiento estudiantil, donde coincidieron unos con otros.

Veamos ahora, en segundo lugar, la actividad del movimiento sindical, que asimismo tuvo un repunte durante la segunda mitad de la década de los sesenta. Las acciones más connotadas se dieron durante el año 1967, que era, recordémoslo, año electoral. Ya en febrero, unos 200 trabajadores de la IUSA -una de las fábricas textiles más importantes, propiedad de la familia de Sola- se habían ido a la huelga por cuestiones salariales y de contrato colectivo. La experiencia resultó exitosa.

En abril estallaría el movimiento huelguístico de mayor impacto y que será recordado por largo tiempo. En una fundidora ubicada en la ciudad de Zacatecoluca, pequeña urbe cabecera del departamento de La Paz, viene habiendo tensiones por las condiciones de trabajo y el reclamo obrero de aumento salarial. Esta situación lleva a la patronal de la fábrica ACERO S.A. a realizar algunos despidos, lo cual no hace sino recrudecer el ánimo de lucha de los trabajadores. Estos, que no sobrepasan los 260 obreros, se lan- 
zan a la huelga por la readmisión de los despedidos y el resto de reivindicaciones laborales.

Es una medida de hecho que no ha buscado el marco jurídico que teóricamente haría posible la huelga legal, lo cual no es nuevo en el país. De hecho la legislación legitima el derecho de huelga, pero prescribe un procedimiento burocrático tan complicado, que en realidad obstaculiza la posibilidad real de ejercer ese derecho constitucional. En más de cuarenta años una única huelga fue realizada siguiendo todos los pasos legales, la cual finalmente fue perdida por los trabajadores. De ahí que la "huelga ilegal" declarada en la empresa ACERO no fuera nada nuevo en el país. El dueño trataba en forma directa con el comité de huelga, como era habitual en estos casos, sin importar en los hechos la legalidad o no de la medida. Lo que contaba era la concreta correlación de fuerzas que hubiera entre los sectores enfrentados. La patronal sabía que siempre podía contar con el apoyo del Ministerio de Trabajo y con las sutilezas de una legislación laboral redactada con el claro propósito de desalentar el recurso obrero del paro de labores para imponer sus demandas.

Nada de eso constituía una novedad. Lo que resultó diferente esta vez fue que esta lucha obrera lejos de transcurrir en el aislamiento, $y$ pese a protagonizarse lejos del escenario de la ciudad capital, consiguió una formidable reacción solidaria. Una serie de empresas de las más diversas ramas y ubicadas en diferentes puntos del país se lanzaron asimismo a la huelga, sin más demanda que la solidaridad con "la justa lucha de los hermanos de ACERO S.A.". El propio 26 de abril, fecha en que estalló la huelga en Zacatecoluca, se sumaban a la misma los trabajadores del puerto de Cutuco, los descargadores del muelle de Acajutla, los ferrocarrileros, etc. La paciente labor de crear federaciones sindicales y redes obreras entre diversas ramas industriales, demostraba estar rindiendo frutos. Tanto la FUSS, Federación Unitaria Salvadoreña de Sindicatos, de influencia comunista, como la pro-gubernamental CGS, Confederación General de Sindicatos, proclamaban juntas su apoyo a la huelga de la fábrica ACERO.

El 28 de abril fuentes sindicales informaban que la huelga de solidaridad estaba siendo seguida por 35 mil obreros. La cifra era probablemente exagerada, pero era indudable la magnitud sin precedentes del movimiento huelguístico. Estaban paralizadas muchas de las empresas principales del país, incluidas algunas caracterizadas por dar un mejor trato a sus empleados. Se habían sumado al movimiento, entre otras, Aceites El Dorado, Pan Lido, industrias lácteas Foremost, las textileras Minerva y El León, la empresa de pastas alimenticias Molinos 
de El Salvador, la fábrica de zapatos ADOC, además de empresas de la construcción, de transportes y portuarias.

La clase obrera salvadoreña, sorprendida de su propia fuerza y alentada por su misma capacidad de ponerse en movimiento, estaba creando una coyuntura excepcional en el país. Tanto el Gobierno como las gremiales empresariales, reaccionando al unísono como instrumentos del conjunto de la clase dominante -que es lo que en el fondo uno y otras eran-, presionaron a la familia Borgonovo, dueña de la fábrica ACERO, para que se diera una solución inmediata al conflicto. No le quedó más remedio que ceder, de modo que el propio día 28 de abril se anunciaba la victoria de los trabajadores que conseguían la totalidad de sus demandas. Había sido una experiencia crucial y además victoriosa, lo que marcaría un momento de auge en la conciencia de clase y la disposición combativa del movimiento sindical.

Calculando mal esa positiva correlación de fuerzas, la FUSS lanzó unos meses más tarde una huelga de panificadores. Había una intención política desestabilizadora, más que una raíz propiamente sindical, lo que era explicable pues el secretario general de la FUSS, Salvador Cayetano Carpio, era al mismo tiempo secretario general del proscrito PCS. El movimiento se entrampó y Carpio decidió asumir un protagonismo personal, a partir del hecho de que él mismo era de profesión panadero y era su sindicato el que se había lanzado a la lucha. Se puso en huelga de hambre, pero este gesto testimonial no iba a cambiar la correlación de fuerzas. Esta vez el movimiento no logró ser extendido y terminó perdiéndose. No obstante, durante varias semanas entre octubre y noviembre de 1967 concentró la atención nacional. Tanto al régimen como a los sectores dominantes quedaba clara la peligrosidad potencial del movimiento obrero sindical y la penetración que del mismo había hecho la subversión comunista.

El año siguiente fue una nueva sorpresa la que se dio desde la dinámica social. En esta ocasión era un sector de empleados públicos que tradicionalmente había sido confiable y sumiso al régimen. Se trataba del magisterio nacional. Se lanzaba a la lucha gremial un día antes de celebrar el Día del Maestro, tomando de ahí su nombre Asociación Nacional de Educadores Salvadoreños, ANDES 21 de junio. Consiguió la comprensión y apoyo de gran parte de la ciudadanía, reforzando tremendamente su prestigio. Varios de sus dirigentes serán después líderes destacados de la izquierda revolucionaria: Mario López, Mélida Anaya Montes, Norma Guevara, Salvador Sánchez Cerén, etc. La influencia del movimiento de maestros excedía el de un sector laboral cualquiera. 
Hay que tomar en cuenta que el peso social del maestro, en una sociedad atrasada y predominantemente rural como la de El Salvador, era considerable. En las pequeñas poblaciones el maestro era, junto al cura párroco y al médico, parte de las "fuerzas vivas". Eran una verdadera autoridad, tan sólo equiparada a la del alcalde, el juez y el jefe del puesto de la Guardia. Normalmente los pueblos se regían por el consenso, más o menos espontáneo, que brotaba de tales cargos y personajes. Hay que entender esto para comprender la repercusión que tuvo cuando el maestro empezó a organizarse gremialmente, a exigir sus derechos y a luchar por ellos, convirtiéndose rápidamente en un fuerte crítico del régimen y en opositor al gobierno. A este fuerte impacto social e ideológico se sumaría pronto otro más, cuando desde los nuevos lineamientos emanados en el Concilio Vaticano II y en la Conferencia Episcopal Latinoamericana de Medellín (1968) muchos sacerdotes se adhieren a la corriente de la "teología de la liberación" y se convierten a su vez en férreos críticos del poder. El régimen verá perder en poco tiempo dos de los pilares fundamentales de su dominación ideológica. Al contrario, va a ser duramente confrontado por esos "intelectuales orgánicos" que ahora ejercen su función y su capacidad desde las filas opositoras.

\section{La politización de la dinámica social}

Tal como hemos descrito, se va dando una preeminencia de la dinámica social durante la segunda mitad de la década de los sesenta, lo que indica el funcionamiento dialéctico de la tríada que preside todo el período y en la que el tercer elemento pasa a confrontar a los dos primeros. También justifica que hablemos de una segunda fase de dicho período. En ella, lo social tiende a asumir un papel dominante, desplazando a lo económico de esa posición, y apoyándose en la dinámica política que se perfila como el factor dominante que a futuro presidirá el signo de los tiempos. En ese lapso inicial, que se corresponde a los últimos años de la década, lo político no presenta todavía contradicción con lo social sino que sirve como simple complemento, que lo refuerza y matiza.

De tal manera que podemos hablar de una politización generada sobre esa base de la dinámica social que se va adueñando con su actividad del escenario histórico, va a ir concentrando sobre sí la atención y preocupación de todos los actores y del sujeto histórico. 


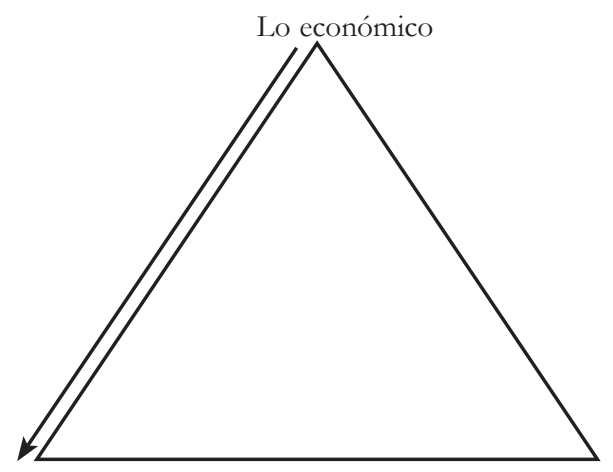

Lo social

Lo político

Todo esto está perfilado solamente como tendencia, pues es pronto aún para que exprese en la realidad fáctica todo la carga de explosividad social y política que potencialmente conlleva. Pero contiene ya en su seno, como bomba de relojería, los elementos que más adelante darán al traste con el apacible y prometedor signo de los tiempos con que había arrancado la década. Ésta terminará siendo la negación de ese signo, tanto en los hechos como en las conciencias, rechazándolo y generando su opuesto, su contrario dialéctico.

Tenemos que verlo más adelante, pero conviene dejarlo apuntado para que se entienda la lógica hacia la que se va, la cual es ya perceptible en los acontecimientos del país a partir de 1967 y 1968. A los elementos de movilización popular que ya hemos referido hay que agregar los concernientes al mundo de la religión, que incluye componentes de doctrina y teológicos de- sarrollados por el Concilio Vaticano Il y Medellín, y que en el terreno de la historia salvadoreña se traducen en una novedosa corriente de pensamiento en el seno de la Iglesia católica. Social y políticamente, más que hablar de "teología de la liberación", debemos decir "movimiento de comunidades de base". Es una realidad social e ideológica nueva, inexistente antes en el país, que va a tener fuerte repercusión.

El espíritu de Medellín se difunde y penetra rápidamente en distintos núcleos cristianos, entre ciertos sacerdotes diocesanos y en algunas órdenes religiosas, en especial, entre los jesuitas. Hay una apertura y tolerancia de parte del Arzobispado de San Salvador, a pesar de que entre los obispos salvadoreños predomina el conservadurismo y resistencia al cambio que la conferencia episcopal del continente está promoviendo. Pero el espacio que se abre por parte del arzobispo monseñor Chávez resulta suficiente 
para permitir que algunos entusiastas sacerdotes se lancen a una labor pastoral de opción preferencial por los pobres, que incluye su concientización y organización. Se prepara a simples campesinos como agentes de la palabra que sirven de multiplicadores y organizadores de las comunidades cristianas de base.

La eficacia del trabajo pastoral en la orientación de Medellín da rápidos y abundantes frutos. Ya en 1965 se ha fundado la Federación Cristiana de Campesinos Salvadoreños, FECCAS, la cual va a extenderse primero por Aguilares, El Paisnal, Chalatenango y pronto al resto del país. El cristianismo, revitalizado por la nueva lectura de los textos bíblicos y la nueva interpretación del mensaje de Cristo, genera un verdadero proceso de conciencia social y política entre el campesinado. La religión deja abruptamente de jugar el papel de justificadora del poder y defensora de la resignación, ya no es más "el sollozo de la criatura oprimida, el corazón de un mundo sin corazón", 88 ahora empieza a actuar en un sentido contrario. De ser fuerza ideologizante pasa a ser desideologizadora, de cómplice de las estructuras de poder y defensora del status quo, pasa a una labor de denuncia y de toma de conciencia de la explotación y de la necesidad de acabar con ella. Preparar el advenimiento del Reino de Dios, partiendo de concebir éste no como algo del más allá, sino como una realidad terrena e histórica, que es parte de los planes de Dios para el ser humano el que encuentre su realización concreta en este mundo.

Siglos de educación cristiana tradicional son cuestionados por esta audaz palabra que en su renovada evangelización va a la fuente misma del cristianismo, la vida de Cristo y las Sagradas Escrituras, haciendo una relectura que resulta coherente pero que contradice la forma convencional e hipócrita de la religión "de los ricos y poderosos". Seguir a Cristo es seguir a Aquél que expulsó a los mercaderes del templo, que rechazaba como falsos profetas a los que pretendían engañar al pueblo, que denunciaba la hipócrita sumisión al poder de escribas y fariseos, que dijo que "será más difícil que un rico entre al Reino de los Cielos a que un camello pase por el ojo de una aguja". En vez de ser un mensaje de resignación, la Palabra es ahora un Ilamado al compromiso y a la acción. Dejar el temor, la indiferencia, unirse a los demás hermanos y juntos caminar para desafiar al poder, al igual que Jesús desafió al poder judío y romano, juntos como pueblo de Dios Ilamado a liberarse, como en el Exodo que liberó a los judíos del poder de Egipto.

Las comunidades cristianas de base y sus promotores serán prontamente acusados de subversión por el régimen, iniciándose su control y represión. Para sus participantes eso no venía sino a confirmar que iban 
por el buen camino. La persecución y el martirio han sido la marca distintiva del cristianismo de los primeros tiempos, de lo más auténtico de la historia de la Iglesia. Lejos de frenar la expansión del movimiento, la represión lo iba a fortalecer con una mística más firme y una convicción más indestructible. El Estado salvadoreño, paradójicamente, al reaccionar en forma represiva va a propiciar que se acelere y radicalice el proceso de politización del movimiento de comunidades de base.

En FECCAS participarán muchos jóvenes que se afilian a la Juventud de la Democracia Cristiana, mientras otros se acercarán a organizaciones marxistas. De hecho, varios altos dirigentes de la futura guerrilla fueron formados inicialmente en el movimiento de las comunidades cristianas de base, donde desarrollaron su sensibilidad social e iniciaron su politización. La propia organización FECCAS tendrá un acercamiento durante los años setenta con la estructura campesina que han creado las Fuerzas Populares de Liberación, (FPL), la llamada Unión de Trabajadores del Campo, hasta fusionarse en FECCAS-UTC y juntas participar en la fundación del frente de masas Bloque Popular Revolucionario (BPR), brazo político de dicha organización guerrillera. En el oriente del país, el Ejército Revolucionario del Pueblo (ERP) también se ha nutrido del trabajo cristiano de base.
En las difíciles condiciones sociales de El Salvador, y en el marco de una feroz dictadura militar que a estas alturas se prolonga ya por cuarenta años, se iba a dar una confluencia lógica entre cristianismo y marxismo. En todo el continente latinoamericano sucede eso y hay incluso diferentes trabajos teóricos dedicados a este tema, así como pensadores de uno y otro campo que han escrito para fundamentar la posibilidad teórica y práctica de que marchen unidos marxistas y cristianos. De hecho, en nuestro país esta unidad se dio en la práctica y es una clave para entender que el movimiento popular revolucionario en El Salvador haya tenido la masividad y tenacidad que tuvo, especialmente en las áreas rurales. Las zonas de más fuerte implantación guerrillera coinciden, y no es casualidad, con aquéllas donde las comunidades eclesiales de base se habían arraigado más.

Pero ésta es una historia que corresponde a la década de los años setenta. En la década anterior, todo esto es simple potencialidad. En un inicio la fuerza política que más se vio beneficiada por las nuevas corrientes de pensamiento en la Iglesia y por la organización de una red de trabajo pastoral fue la democracia cristiana. Conectó estos planteamientos con la tradicional doctrina social de la Iglesia -que oficialmente inspira al movimiento cristiano-demócrata mundial- para 
dar coherencia a esa posición que le permitía acercar a mucha base popular a las filas de su partido. El PDC se perfiló pronto como la fuerza opositora principal, la que arrastraba más base social y con mayor número de militantes. No es ajeno a este rápido crecimiento la confluencia que señalamos con el cristianismo progresista de la opción preferencial por los pobres. El programa del PDC, centrado en la llamada "revolución de los pobres", trataba de conciliar esa base de concientización cristiana con el latente anticomunismo y la tendencia populista que lo impregnaba. Poco a poco se va a ir desgastando, en la medida que el proceso histórico se radicalice a lo largo de la década siguiente, pero durante un plazo de por lo menos diez años el PDC se mantendrá como la principal fuerza opositora, con fuerte implantación popular.

La derecha aglutinada en las estructuras protectoras del régimen político no iba a quedar impasible ante la creciente fortaleza de la oposición y la acentuada agitación social. Una primera iniciativa tendiente a contrarrestar la peligrosa situación que se iba generando en el campo fue la creación de la Organización Democrática Nacionalista, ORDEN. Fue un militar, el coronel Medrano, quien tomó la iniciativa de su fundación. Funcionaba en parte como correa de transmisión del partido oficialista PCN, movilizando campesinos en las coyunturas electorales, y en parte como estructura autónoma que se encargaba de complementar la vigilancia represiva que ejercía la Guardia Nacional en el área rural. Al control rutinario y el patrullaje preventivo que realizaban las parejas de guardias, se unía ahora el espionaje permanente y la denuncia de pobladores de la zona que vivían en el lugar y conocían perfectamente a sus vecinos, sus ideas y sus actividades. ORDEN Ilegó a tener 60 mil miembros en los años sesenta, de manera que era un formidable aparato paramilitar de apoyo al régimen. Algunas estructuras de ORDEN recibieron armamento del gobierno y empezaron a practicar directamente la represión, no siempre motivada políticamente, pues en ocasiones era expresión de venganzas y rencillas personales.

En la medida que crecía la agitación social en el país, el mismo Medrano organizó otros organismos encargados de aplicar más brutal y especializadamente la represión: surgió la Mano Blanca, un antecesor de los fatídicos escuadrones de la muerte, que funcionaba en las instalaciones de la Guardia Nacional, de la que Medrano era el Director. Más tarde creará la Agencia Nacional de Seguridad Salvadoreña, ANSESAL, como órgano de inteligencia del Estado, a partir de los archivos de la Guardia. Ahí se desempeñó el mayor d’Aubuisson hasta ser dado de baja de las filas del Ejército. 


\section{La guerra con Honduras: ruptura dialéctica, salto cualitativo, desenlace histórico}

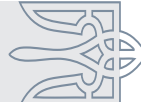

No debiera extrañar que encontremos al mismo personaje, Medrano, ahora ascendido a general, jugando un papel protagónico en la guerra con Honduras. Debe analizarse eso como un ingrediente histórico revelador. El mismo militar que ha sido el estratega de la represión interna, ideólogo de la doctrina de seguridad nacional y asesor del presidente Sánchez Hernández en esta materia, que ha precisado quién es en El Salvador "enemigo interno" y le ha puesto nombre y apellidos, frecuentemente con resultados mortales, es en 1969 la más publicitada figura de la batalla contra el "enemigo externo". No sólo eso sino que contribuyó grandemente a trazar una estrategia salvadoreña de confrontación a fin de arrastrar al país a la guerra contra la vecina nación.

Lejos de verse como algo casual, debe ser visto como un signo revelador. Sostenemos que la confrontación bélica entre Honduras y El Salvador debe ser analizada como un acontecimiento propio de la dinámica política. Es decir, que fue básicamente resultado de decisiones motivadas políticamente, tanto por parte del gobierno hondureño como del salvadoreño. Para decirlo breve y rotundamente: la guerra fue una decisión política.

Del lado hondureño deben verse los antecedentes de la tímida reforma agraria de 1962 emprendida por el presidente Villeda Morales, recortada el año siguiente por presión del poderoso sector ganadero y de las compañías bananeras transnacionales. Estos intereses se impusieron plenamente con el golpe de Estado del 3 de octubre de 1963 dado por el coronel López Arellano. Éste gobernó en forma represiva los primeros años, pero más tarde fue introduciendo componentes reformistas a su política. Fue bastante tolerante en 1969 con la oleada de ocupaciones ilegales de tierra que se produjeron y se apoyó en el Instituto Nacional Agrario, INA, para promover cooperativas según el modelo de una organizada en 1966 Ilamada "Guanchías Limitada". Ese mismo año 1969 se conformó la UNC, Unión Nacional de Campesinos, y la CGTH, Confederación General de Trabajadores de Honduras. Tuvo también el Gobierno que afrontar un fuerte movimiento huelguístico, protestas por los nuevos impuestos y amenazas de comerciantes e industriales de realizar un paro empresarial. ${ }^{99}$

Ante esta situación de acoso en que el Gobierno de López Arellano se encontraba, la campaña propagandística gubernamental contra los "intrusos" salvadoreños parecía al inicio una simple maniobra de diversión, calculada para desviar la atención de los verdaderos pro- 
blemas del país. Pero astutamente el Gobierno empezó a vincular la supuesta solución del problema agrario con la expulsión de los "forasteros", a quienes injustamente se acusaba de ser la causa del mismo. Se planificó una especie de reforma agraria en la que repartirían tierras a los campesinos hondureños sin afectar, ni a los grandes terratenientes, ni a las compañías bananeras: la clave era hacerla a costa de los pequeños propietarios y ocupantes ilegales de procedencia salvadoreña. Pero no debe sobreestimarse en el análisis este aspecto socio-económico. El tal reparto de tierras no Ilegó nunca a realizarse. El cálculo principal del Gobierno hondureño fue precipitar la guerra con El Salvador para "fabricar" el consenso, exacerbar el sentimiento patriótico y generar la unidad nacional. Aunque Honduras perdió militarmente la contienda bélica, la estrategia de López Arellano resultó exitosa para sus propósitos.

De lado salvadoreño igualmente encontramos una similar voluntad guerrerista, asimismo políticamente motivada. Ya hemos visto cómo la situación interna se le iba complicando al Gobierno del general Sánchez Hernández. Eso a pesar de que El Salvador mantenía un alto índice de crecimiento económico y venía aprovechándose del marco favorable del MCCA para penetrar en el mercado centroamericano, en especial en el nicaragüense y en el hondureño. Pero las tensiones sociales aumentaban y tendían a tener expresión política opositora. La válvula de escape de la emigración no parecía ser suficiente para mitigar la presión de la olla social salvadoreña. Por ese motivo es lógico que el Gobierno salvadoreño se alarmara cuando su homólogo de Honduras empezó a ejercer presión sobre los inmigrantes salvadoreños y amenazaba con expulsarlos.

Sánchez Hernández se abocó a buscar la comprensión de Estados Unidos ante la extraña actitud tomada por el régimen hondureño. Según su razonamiento, la alta concentración demográfica salvadoreña constituía por sí misma un peligro de seguridad nacional y si los norteamericanos deseaban impedir que el comunismo prosperara debían convencer a Honduras que permitiera el libre flujo migratorio de salvadoreños, como desde siempre había sido. Al fin y al cabo -argumentaban los diplomáticos salvadoreños- a Honduras le sobraban tierras y no le era ningún problema acoger a esos inmigrantes. El Salvador confiaba en que Estados Unidos y la Organización de Estados Americanos, OEA, se iban a mantener neutrales si estallaba el conflicto entre ambos países.

Ante la actitud cada vez más agresiva de Honduras y con las primeras informaciones de violencia contra los compatriotas en ese país, el Gobierno salvadoreño lanzó una dura campaña propagandística 
y comenzó a prepararse para la guerra. Se usó a los medios de comunicación, siempre complacientes a satisfacer los requerimientos del poder, para exagerar y dramatizar las noticias de persecución contra los salvadoreños y de supuestas "barbaridades" de que eran víctima los connacionales. Relatos de mujeres a las que les habían cercenado los pechos y habían caminado en su huida cientos de kilómetros eran, a todas luces, increíbles pero servían para levantar la indignación popular y fomentar un odio fratricida contra los hondureños. La normal rivalidad por una competencia de fútbol, clasificatoria para el Mundial, fue utilizada en junio de 1969 para terminar de encender las pasiones. Poco días después del segundo partido, El Salvador lanzó, sin previo aviso, su invasión militar. Había empezado la "guerra del fútbol".

Los militares salvadoreños estaban convencidos de un rápido triunfo. Su ejército, con el apoyo inestimable de la aguerrida Guardia Nacional, casi duplicaba en número a los efectivos hondureños. Estos contaban además con armamento muy anticuado, propio de la primera Guerra Mundial, mientras El Salvador tenía los G-3 de fabricación alemana, remanentes de la segunda Guerra Mundial. Aún siendo ambos ejércitos afectados por las condiciones de atraso y subdesarrollo, ineptos para librar una guerra moderna, el poder de fuego del salvadoreño era muy superior al de su enemigo.
Solamente en la aviación tenía Honduras ventaja. El Salvador necesitaba, por estrategia militar, lanzarse a una guerra no declarada, para así bombardear por sorpresa los aeropuertos hondureños antes de que sus aviones pudieran despegar.

Las tropas salvadoreñas penetraron centenares de kilómetros en territorio hondureño, encabezadas por la Guardia Nacional bajo el mando del general Medrano. La aviación hondureña, parcialmente destruida en tierra, no pudo bombardear San Salvador, como se temía. Pero fue una victoria pírrica. A las cien horas, la OEA amenazó con intervenir si El Salvador no congelaba su invasión y mandaba sus tropas de regreso.

Militarmente victorioso, El Salvador resultó derrotado políticamente. Estados Unidos no lo respaldó en su aventura militar. Ante la comunidad de naciones latinoamericanas era el agresor, por haberse lanzado con su invasión sorpresiva a una guerra no declarada. A pesar de todo, Sánchez Hernández vio coyunturalmente fortalecida su posición mientras el general Medrano, el carnicero que encabezaba la represión interna, fue ahora recibido como un héroe a su retorno triunfal de Honduras. Como evento de política interna, la operación -desastrosa a nivel internacionalhabía proporcionado abundantes réditos al Gobierno. La emisión de los "bonos de la dignidad nacional" 
fue un éxito y el respaldo popular a la iniciativa militar del Gobierno muy grande. Nadie en El Salvador le daba mayor credibilidad a los reportes de las "barbaridades" cometidas a su vez por los combatientes salvadoreños contra la población civil hondureña, de forma notoria por los elementos de la Guardia Nacional. El revanchismo y el sentimiento de venganza habían prevalecido sobre el buen juicio. La totalidad de partidos, incluida la oposición -hasta el mismo Partido Comunista (después se haría su autocrítica por ello)- había respaldado al Gobierno en ese momento, "cuando la Patria reclama a todos sus hijos". El nacionalismo había sido artificialmente exacerbado y el régimen gozaba de un respiro.

Por poco tiempo. El MCCA había resultado definitivamente destruido con la guerra y era El Salvador la nación que más tenía que perder con ello. Además, la agresión militar fue para el Gobierno hondureño el mejor pretexto para desembarazarse por fin de gran parte de la indeseada inmigración salvadoreña. Se calcula en unos cien mil compatriotas los que vinieron expulsados de regreso, en total penuria, habiendo tenido que dejar la totalidad de sus pertenencias en Honduras. A la difícil situación social ya existente, se agregaba ahora esta oleada de compatriotas empobrecidos, sin trabajo y muchos incluso sin techo. Pasada la primera euforia solidaria y nacionalista, pronto este peso añadido vendría a desequilibrar aún más la ya inestable situación social del país.

El éxito político gubernamental fue, por tanto, temporal y efímero. La dinámica política se había vuelto a imponer según el signo de unidad nacional con que había comenzado a dominar al principio de la década. Pero muy brevemente. No podía ser de otro modo. Se repetía algo que suele darse en la historia. A ello hacía referencia ese gran pensador del acontecer histórico que fue Hegel: "El muerto levanta la tapa de su ataúd, intenta incorporarse, trata de escapar". No parece consciente de su estado, de que está muerto y enterrado, hace por regresar al pasado. Pero es imposible. "La rueda de la historia nunca gira para atrás," Es por ello -explicaba Hegel- que a los Borbones hubo que expulsarlos dos veces, Napoléon tuvo que ser nuevamente derrotado.

Pues bien, en forma similar se dio en El Salvador a fines de la década de los sesenta ese ilusorio revivir de un tiempo pasado que ya estaba muerto. Por un corto período parecieran las élites dominantes lograr su propósito de regresar para atrás la rueda de la historia, de retornar al momento inicial de euforia nacionalista y de unidad patriótica que predominó a partir de la Constitución de 1960. Fue sólo como el instante de fortaleza postrera del enfermo terminal, agonizante, que antes de expirar definitivamente 
parece a punto de reponerse, para alarma de los deudos y herederos. Así, esa coyuntura en que la dinámica política pasó al primer plano, según un signo que ya no le correspondía. Pronto va a ser revertido ese momento y recuperado el signo de los tiempos que le es propio, según una dinámica política que reaparece con un contenido cambiado respecto al anterior. Es esta dinámica que jugará como dominante en el tiempo de los setenta y que no se parece en nada a la que fue determinante durante la década de los años sesenta. Abre el paso hacia ella el acontecimiento básicamente político de la guerra entre El Salvador y Honduras.

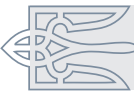

\section{Dialéctica del signo de los tiempos}

Recapitulando lo que llevamos dicho hasta ahora, el período de la década de los años sesenta del proceso histórico salvadoreño podemos representarlo gráficamente mediante la figura del triángulo. Corresponde con la tríada dialéctica que preside la época. En ella "lo político" ha jugado el rol de la dinámica determinante.

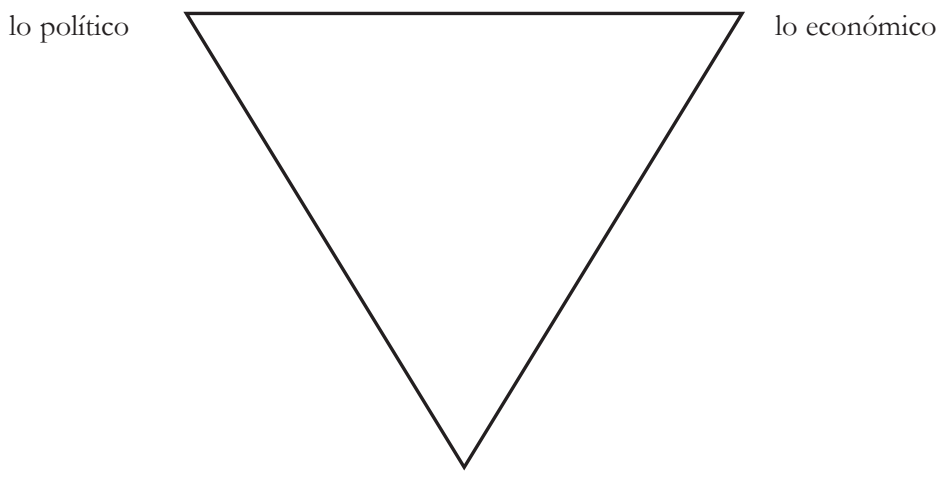

lo social

La dinámica dominante es "lo económico", que aparece a la derecha del triángulo. Todo el período viene determinado en primera instancia, "dominado" por los eventos en la esfera de la economía. Concuerdan con los de la política en un inicio, después tendrán contradicción.
El conflicto entre la dinámica política y la económica, entre factor determinante y dominante, conlleva la aparición del tercer elemento, que aparece como vértice inferior en nuestra figura del triángulo. Esta dinámica resultante entrará en contradicción con las dos anteriores, desarrollándose así una dialéctica 
triangular. Por lo mismo, "lo social" tenderá a desplazar de la escena a "lo político" y "lo económico", con lo que el movimiento dialéctico se prolonga hacia un cuarto elemento que impulsa dicha dinámica social en cuanto negación de la negación o dinámica resultante.

dinámica política

dinámica económica

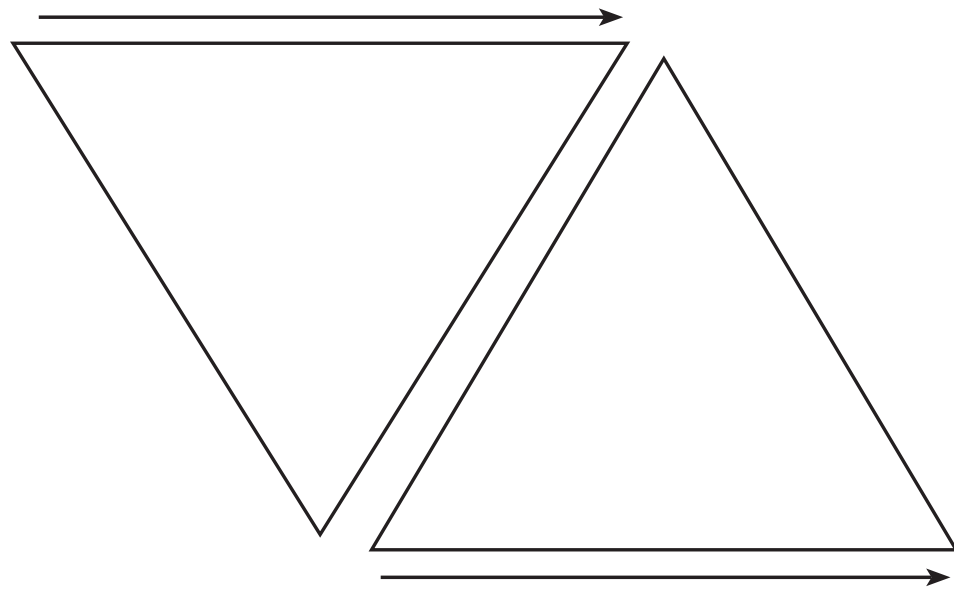

dinámica social

dinámica política

La primera tríada dialéctica se complementa ahora con una segunda, son dos triángulos invertidos. La dinámica social es el tercer vértice del primero; respecto al segundo, es el segundo vértice. Es decir, temporalmente juega el papel de dinámica dominante en esta segunda tríada que configura una nueva fase. El signo de los tiempos, progresista y esperanzador, resulta negado tendiendo a invertirse ese contenido en esta segunda fase. Corresponde con la descripción de los hechos a partir de 1967 y 1968.

La "nueva" dinámica política, que tenemos como cuarto vértice de la cuádrupla, tenderá a constituirse en dinámica dominante más adelante, como lo sugiere su lugar a la derecha en la figura. Pero esta consideración nos lleva a un período posterior, al momento de las elecciones presidenciales de 1972, sobrepasando el período de la década que analizamos como antecedentes de nuestro estudio. Quedémonos en este momento intermedio en que está sólo sugerido el movimiento dialéctico posterior. Tenemos en él un paralelogramo, si se prefiere, un rombo recostado, que incluye dentro suyo las dos fases en que se nos ha descompuesto el período de la década de los sesenta. 


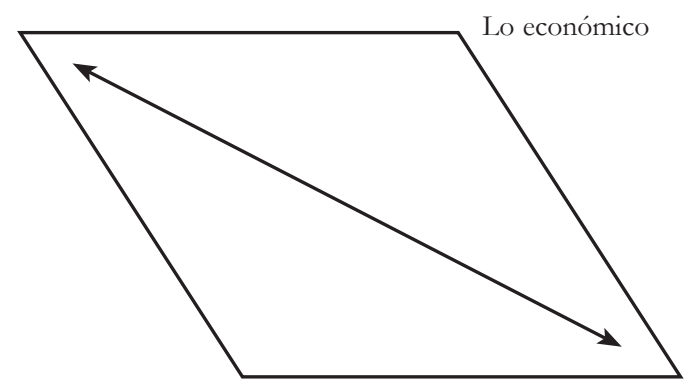

Pongamos atención a los vértices extremos que diagonalmente se oponen en la máxima tensión. La dinámica política se repite ahí. Vuelven a ser iniciativas y acontecimientos en la esfera de lo político, pero no es ya la misma dinámica, pues su contenido ha variado sustancialmente. Entre ambas dinámi- cas se da justamente la mayor contradicción. Es decir, no sólo no son la misma sino que sus contenidos son opuestos, se niegan mutuamente. Por tanto, son una la negación de la otra. Los vértices extremos de la cuádrupla dialéctica representan a la dinámica política negándose a sí misma.

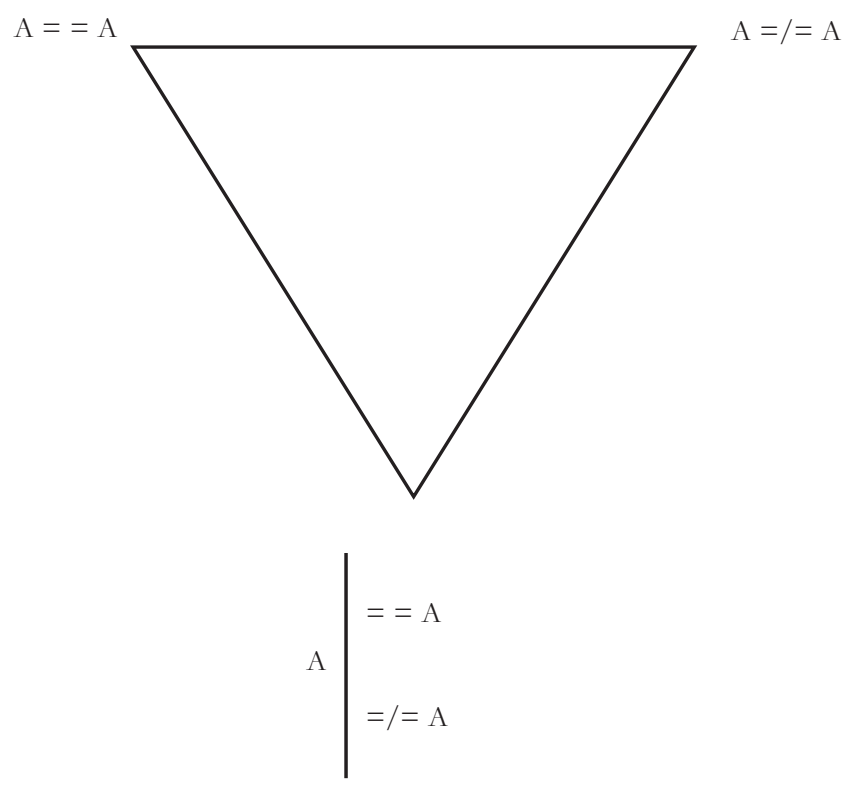


Hagamos aquí una pequeña disgresión teórica para aclarar y justificar lo que planteamos. Nos auxiliará la lógica dialéctica expuesta por Hegel. La identidad primera (A $==$ A) se tensiona con su negación, con la no-identidad, o momento de la diferencia $(A=/=A)$. El vértice inferior expresa la resolución de dicha contradicción: la "cosa" (A) es tanto idéntica a sí misma como diferente de sí. En esta dialéctica identidad y diferencia son lo mismo; "la cosa" expresa esa "identidad entre la identidad y la no identidad". Expresa la dialéctica real del viviente, que sigue siendo él mismo pese su continuo cambio.
Ahora bien, Hegel no terminaba ahí su exposición de la dialéctica entre la identidad y la diferencia. El desarrollo permite un cuarto elemento: representar una cuádrupla que deja incluida en su seno la tríada anterior. Se trata de un movimiento ulterior donde "la cosa" no sólo se diferencia sino que se niega a sí misma. Es el momento en que $A$ es idéntico a no-A. Es un punto máximo del movimiento dialéctico, pues en él se genera la negación de un elemento de sí mismo. La cosa genera su propio opuesto, es ahora lo contrario de lo que era en un inicio.

$$
\mathrm{A}==\mathrm{A} \quad \mathrm{A}=/=\mathrm{A}
$$

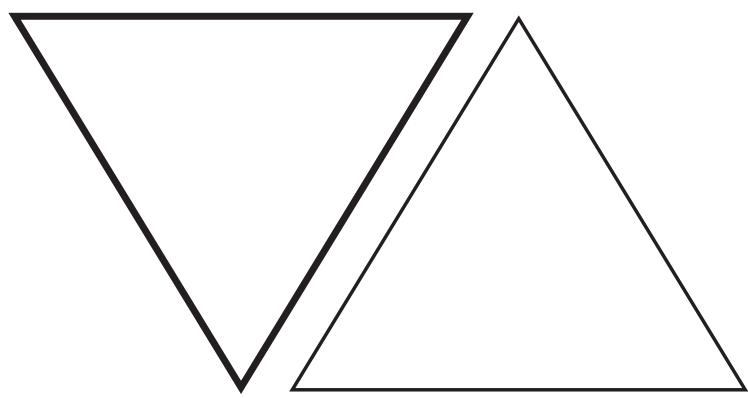

$\mathrm{A} \mid \begin{aligned} & =\mathrm{A} \\ & =/=\mathrm{A}\end{aligned}$

$$
\mathrm{A}==\text { no } \mathrm{A}
$$

Es lo que podemos representar con el rombo y sus vértices extremos en contradicción el uno con el otro. Una vez puesto en movimiento, A termina generando no-A, según esta lógica dialéctica. 
Pues bien, esa misma figura romboidal es la que se nos ha representado como síntesis de la década de los sesenta. También en ella se da una tensión máxima, con la dinámica política repitiéndose a ambos extremos. Consideramos que se trata de esta misma lógica dialéctica que acabamos de exponer de la mano de Hegel. Es decir, lo que tenemos ahí es la dinámica política negándose a sí misma, convertida a fines de la década de los sesenta en el no-A con respecto al afirmativo A que teníamos al principio del período. En el plazo mínimo de unos diez años, el acelerado dinamismo histórico salvadoreño ha dado de sí toda esa riqueza dialéctica, completando su movimiento en forma de cuatro elementos, como cuádrupla y no sólo como la tradicional tríada dialéctica. De tal modo nos queda representado este rico período que culmina negando lo que primero afirmó.

Al Ilenar el esquema teórico con toda la riqueza empírica de los acontecimientos que se fueron dan- do a lo largo de los años sesenta en El Salvador, podemos comprender el alto grado de correspondencia que hay, en este caso, entre teoría y práctica. Se iluminan mutuamente. El ejemplo histórico puede servir como modelo de aplicación para mejor entender lo que plantea la teoría. Pero también a la inversa. Desde lo teórico encontrar la clave explicativa de la masa de datos e informaciones que poseemos del proceso y que se presentan como una maraña difícil de desentrañar, como un laberinto fáctico donde fácilmente nos perdemos en la paradoja de que cuanto más sabemos de nuestra historia, menos sabemos de ella, más lejos parecemos estar de una comprensión real y verdadera. La única forma de cortar el nudo gordiano es mediante el recurso a la teoría. En nuestra propuesta, la dialéctica es la herramienta principal.

Desde ella podemos descubrir y resumir sin dificultad el significado de este fragmento de historia nacional. Lanzado el proceso a un impulso democratizador, que 
intenta con una apertura política mitigar los riesgos de penetración del modelo revolucionario cubano, va a encontrar en la dinámica económica desarrollista la palanca para hacer viables los cambios estructurales que hagan posible la estabilidad política deseada. Pero el modelo económico regional al que se inserta El Salvador presentará la limitante de ser parcial en sus efectos positivos. La prioridad nacional tiende entonces a verse desviada hacia esos intereses parti- culares que resultan especialmente favorecidos. La intención inicial se ve desmentida por los hechos, el discurso político contrarrestado por la realidad económica y finalmente serán los efectos sociales de esa doble relación los que impongan un nuevo contenido al signo de los tiempos. Empieza a generarse una tendencia a la politización de la crisis social. La política vuelve a tener preeminencia, pero con un gran contraste respecto lo que había sido al principio del período.

dinámica política

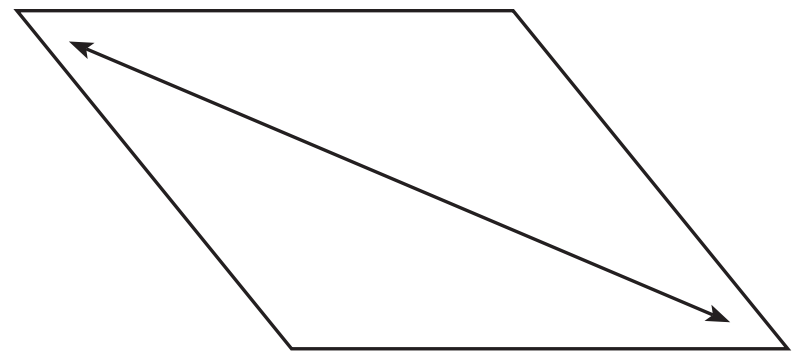

dinámica política

Tenemos, por ello, que la dinámica resultante tiene el contenido de la crisis social: la década ha generado una aguda conflictividad social. Esta lectura va a quedar complementada con la interpretación de la cuádrupla dialéctica. La politización de lo social conlleva que nuevamente la dinámica política aparezca, esta vez, como negación de la pretensión nacional y desinteresada que tenía anteriormente. No ha habido y no va a haber real democratización. A lo que se encami- na el proceso es al endurecimiento de la dictadura. No se consolidó el momento de unidad nacional. A lo que va la historia es al quiebre de la cohesión nacional y a la configuración de dos bloques que avanzarán hacia el drama de la guerra civil. La esperanzadora década termina en un gran fiasco. Al hacer balance de lo que nos heredó, resulta lo contrario de lo que pretendía ser, de lo que en su momento se pensaba que era. Es la década que nos aboca hacia la confrontación. 
Al mirar el conjunto de la década de los sesenta desde la perspectiva centroamericana, queda clara una cosa: el MCCA resultó en un experimento fallido. Tal como había sido diseñado, difícilmente podía terminar más que en un fracaso. La estrategia de sustitución de importaciones presentaba una falla que, vista a la distancia, resulta obvia. Cada uno de los países de la región pretendía venderles los mismos productos a los demás. Sin una mínima especialización por país ni mayor diversificación, partiendo las naciones del istmo de parecida estructura productiva, los esfuerzos de cada una por industrializarse y exportar tenían que chocar necesariamente con los intereses recíprocos de las demás. El modelo ISI como tal no soportó la prueba de la práctica. En realidad, no debería haber pasado tampoco el examen teórico. Los estrategas de la CEPAL y sus contrapartes en los gobiernos centroamericanos reprobaron la asignatura.

Ciertamente, la región centroamericana creció aceleradamente en la época, manteniendo un impulso que ya venía de la década de los años cincuenta. Se ha calculado que entre 1950 y 1978 tuvo un crecimiento anual promedio superior al $5.3 \%$, lo que motivó que se hablara de un "boom" del desarrollo centroamericano. ${ }^{1010}$ Pero no por ello conseguirían los países centroamericanos desprenderse de "la tutela" de Estados Unidos ni de la fatal dependencia hacia las multinacionales y el capital extranjero. En realidad, los pagos de utilidades e intereses por inversiones extranjeras directas y por créditos internacionales, en lugar de disminuir, aumentaron dramáticamente durante la experiencia del MCCA. Mientras en 1961 Centroamérica tuvo que pagar 18 millones de dólares en ese concepto, en 1970 la cifra ascendía ya a 120 millones de dólares. ${ }^{1111} \mathrm{La}$ dependencia económica no decrecía sino que se incrementaba con el supuesto "desarrollo". La industrialización era un instrumento más de la dependencia -dependencia de materias primas, de maquinaria, de tecnología, de patentes, de conocimiento-, en vez de ser un trampolín para saltar hacia una mayor independencia económica.

Por otra parte, debe relativizarse la importancia que tuvo el MCCA sobre el crecimiento económico. Ya hemos indicado que se venía con unas buenas tasas en la anterior década de los cincuenta. Pues bien, al examinar los datos de la década posterior, los setenta, en vez de encontrar un dramático descenso, como sería de esperar tras la ruptura del mercado común regional, hallamos que las cifras no sólo se mantienen, sino que suben. Según datos de la propia CEPAL, Centroamérica creció un $6.0 \%$ entre 1960 y 1965 , en el siguiente lustro el PIB global 
descendió a 5.1\% pero, curiosamente, volvió a tener un repunte de $5.4 \%$ entre 1970 y 1978 . El mismo fenómeno se observa en cada uno de los países. Honduras, uno de los menos favorecidos, creció durante la primera mitad de la década de los sesenta un $5.2 \%$, bajando en la segunda mitad a $4.1 \%$ y recuperándose al $4.4 \%$ de aumento en su PIB en los setenta. El Salvador, uno de los más beneficiados, en el primer lustro de los sesenta alcanzó el $6.8 \%$ de crecimiento del PIB, en los siguientes cinco años creció sólo un $4.5 \%$ y tuvo una recuperación del $5.2 \%$ entre 1970 y 1978 . Lo cual indica que el impulso al crecimiento económico no estaba tan estrechamente ligado al mecanismo de integración regional, como se suele afirmar.

EI MCCA generó, indudablemente, un marco favorable para el crecimiento económico de Centroamérica, el cual fue acelerado en algunas naciones y más lento en otras. Pero al mismo tiempo incrementaba los desequilibrios. Ya hemos visto el contraste de cifras del crecimiento económico entre Honduras y El Salvador. Si examinamos la evolución del intercambio comercial entre ambos países, comprobaremos lo inviable de su relación bilateral, porque se vuelve crecientemente desfavorable para uno de ellos.

En 1960, las exportaciones hondureñas a El Salvador suponían
15 millones 748 mil colones frente a importaciones de productos salvadoreños por un valor de 9 millones 859 mil colones. La balanza comercial bilateral era en ese momento favorable a Honduras en cerca de seis millones de colones. Para 1967, Honduras consigue exportar casi el doble, pero sus importaciones de El Salvador se han más que cuatriplicado. A estas alturas tiene un déficit en el comercio bilateral de más de 19 millones de colones. Entre enero a julio de 1967, Honduras exportaba a El Salvador por valor de 18 millones 683 mil colones y en el mismo período del siguiente año lo hacía por 21 millones 508 mil colones; pero El Salvador saltaba de 27 millones 833 mil colones durante el primer semestre de 1967 a 33 millones 72 mil colones en igual período de 1968. El déficit comercial de Honduras se había visto incrementado, en tan sólo doce meses, en 2 millones 414 mil colones.

La relación de dependencia en que está el conjunto de Centroamérica respecto los países más desarrollados tiende a reproducirse al interior de la región, donde unas naciones van a asumir el papel del imperialismo económico del que, por otra parte, son ellas mismas víctima. No es exageración. En 1967, Honduras tiene un déficit en su balanza comercial con El Salvador cercano al que tiene con Estados Unidos: con el primero de 16 millones $441 \mathrm{mil}$ lempiras mientras con el segundo es de 17 millones 44 mil lempiras. 
El desequilibrio no es solamente cuantitativo. También lo es cualitativo. Mientras lo que exporta Honduras a El Salvador son en un 61.6\% alimentos y materiales crudos y sólo en un $33.1 \%$ productos manufacturados, El Salvador en cambio lo que exporta al vecino país son únicamente $20.3 \%$ alimentos y materiales crudos, mientras el $79.6 \%$ del total de sus exportaciones a Honduras lo constituyen los productos manufacturados. ${ }^{1212}$ De ahí la conclusión a que Ilegaba un analista: "...existe en el intercambio entre Honduras y El Salvador una rígida y elocuente especialización productiva donde Honduras asume el papel de país agroexportador, proveedor de alimentos en bruto y materias primas; y El Salvador asume la función de productor y exportador de productos manufactureros..."13

En 1968, El Salvador exporta a Honduras por valor de unos 42 millones de colones, de los cuales 26 millones corresponden a manufacturas. El impacto en un mercado reducido, como el de Honduras, era considerable. Su Producto Bruto Industrial era de unos 216 millones de colones: la importación de manufacturas salvadoreñas suponía alrededor de un $12 \%$ de su producción industrial total. Las importaciones hondureñas de productos manufacturados eran en un $50 \%$ de rubros tradicionales (textiles, calzado, productos alimenticios, vestuario, muebles, artículos de cuero e hilados) que competían con la incipiente industria local.
En vísperas de la confrontación militar con El Salvador, en Honduras circulaban hojas volantes promovidas por el Gobierno: "COMPATRIOTA. Unete al boicot: no consumas productos hechos en El Salvador." Y seguía una lista de marcas y productos. Detrás del discurso de la CEPAL para abrir una etapa de colaboración entre los países de la región, lo que se dio realmente fue una exacerbación de la competencia. Los países perdedores en ella iban, lógicamente, a buscar protegerse.

Tras la guerra quedó cortada toda relación comercial entre El Salvador y Honduras. Un tiempo más tarde, el 30 de diciembre de 1970, Honduras restableció los gravámenes a los productos centroamericanos para proteger su propia base productiva, retirándose de hecho de la zona de libre comercio. Le seguiría también el otro país desfavorecido con el MCCA. Tras el terremoto de Managua, en diciembre de 1972, Nicaragua aprovechó la coyuntura para imponer regulaciones a las importaciones de El Salvador y Guatemala y ya no las levantaría. Quedaba desmantelado el legado del MCCA y pendiente la tarea histórica de búsqueda de mecanismos idóneos de integración económica regional.

Puesto que el modelo de integración no funcionó según el planteamiento de generar un desarrollo "hacia adentro", sino que 
por el contrario el mecanismo real fue de desarrollo "hacia afuera", es bastante lógico que no haya producido la mejora en la situación social que esperaban sus promotores. No hubo una ampliación suficiente del mercado interno, pues el énfasis estaba en conquistar los mercados regionales externos. Las estructuras de propiedad y acceso a la tierra quedaron, por lo general, intocadas. De ahí las crecientes presiones sociales en el ámbito rural, principalmente en la segunda mitad de la década. La discusión sobre la convenciencia o no, la necesidad o no, de una reforma agraria resultará impostergable a fines de la década. Así fue en los dos países donde hizo crisis el MCCA, Honduras y El Salvador, que heredan este tema a la siguiente década.

Dado que la modernización que se proclamaba en los discursos no había resuelto la transformación de las estructuras de poder económico y aumentaba la conflictividad social, pronto se le dio prioridad al otro componente de la estrategia que propugnaba la Administración norteamericana: la doctrina de seguridad nacional. La tímida apertura política en realidad terminaba abriéndole paso a la militarización del Estado y a formas de control represivo. Tras el amago de la democratización venía el terrorismo de Estado.

Era congruente con la óptica de Washington: "Detrás de esas ambiciosas reformas (las de la Alianza para el Progreso) se escondía un operativo de contrainsurgencia: se trataba de derrotar a la revolución cubana y a los movimientos guerriIleros que amenazaban multiplicarse donde hubiera terreno propicio para ello, con modernización y democracia efectiva. (...) Las clases dominantes resistieron y sabotearon la mayoría de reformas de contenido social (...) Poco importó, en el contexto de la guerra de Vietnam, que los objetivos de democracia política y participación popular, presentes en el plan original, quedaran archivados para un futuro de mejor oportunidad. La conjura de la amenaza subversiva era un éxito de los militares y de las clases dominantes, a los cuales, por lo tanto, no era conveniente importunar."1414 Ya Kennedy lo había dicho: quien se opusiera a la revolución pacífica sería responsable de la revolución violenta. ${ }^{1515}$ Fracasada la primera, no quedaba ahora sino prepararse para la segunda. 
Notas

1 La mayoría de cifras que citamos en esta sección están extraídas de Colindres, E., Fundamentos económicos de la burguesía salvadoreña, UCA Editores, San Salvador, 1977.

2 White, A., El Salvador, Praeger, London, 1974; citado por Colindres, opus cit.

3 Datos citados por Colindres, opus cit.

4 Los datos que se manejan en esta sección han sido extraídos de Carías, M. V. y Slutzky, D., La guerra inútil. Análisis socio-económico del conflicto entre Honduras y El Salvador, EDUCA, San José, 1971.

5 Documento incluido en Valle, V., Siembra de vientos. El Salvador 1960-69, CINAS, San Salvador, 1993.

6 "En El Salvador diecinueve familias controlaban la cuarta parte de la producción algodonera en 1972-73 y entre ellas descollaban como los principales productores Dueñas, Wright y Kriete." La cita es textual de Guerra-Borges, A., "El desarrollo económico", en Pérez Brignoli, H. (ed.), Historia General de Centroamérica, tomo V, p. 30, FLACSO, San José, 1994.

7 Las cifras que se citan en esta sección están tomadas de Carías/Slutzky, opus cit.
8 Expresiones utilizadas por Marx en su crítica histórica a la religión, en su Prólogo a la Crítica de la Filosofía del Estado de Hegel, opus cit.

9 Las informaciones que aquí se mencionan pueden encontrarse más desarrolladas en Guerra-Borges, A., "El desarrollo económico", y en Rojas Bolaños, M., "La política", ambos textos en Pérez Brignoli, H. (ed.), Historia General de Centroamérica, tomo V, FLACSO, San José, 1994.

10 Cálculos hechos por Gert Rosenthal y citados por Ellacuría, I., "Factores endógenos del conflicto centroamericano: crisis económica y desequilibrios sociales", en Veinte años de historia en El Salvador (1969-1989). Escritos políticos, tomo I, UCA Ed., San Salvador, 1991.

11 Guerra-Burgos, opus cit.

12 Cálculos para 1967 en base a datos del Anuario Estadístico del Ministerio salvadoreño de Economía realizados por Waiselfisz, J., "El comercio exterior, el mercado común y la industrialización en relación al conflicto", en Carías/ Slutzky, La guerra inútil, opus cit.

13 Waiselfisz, ibíd., pp. 179 y 180.

14 Pérez Brignoli, H., Breve bistoria de Centroamérica, Alianza Editorial, Madrid, 1988, p. 149.

15 Guerra-Borges, opus cit., p. 77. 